\title{
A fundação do Sporting Clube de Braga
}

\author{
João M. Fernandes ${ }^{1} \quad$ José Bastos Machado²
}

1 Dep. Informática, Universidade do Minho, Braga, Portugal

2 investigador independente

\section{Resumo}

O Sporting Clube de Braga (SC Braga) é um dos mais importantes clubes portugueses, comemorando oficialmente em 2021 o seu centenário. A data da sua fundação é contudo uma questão não totalmente resolvida, na medida em que subsistem dúvidas sobre quando o clube foi efetivamente criado. Este artigo aborda a questão da fundação do SC Braga, trazendo para a discussão novos dados e documentos que permitem afirmar que o clube foi fundado no dia 20 de março de 1919 e constituído no dia 19 de fevereiro de 1921.

\section{Palavras chave}

Desporto, História, Futebol, Braga, Sporting Clube de Braga, Fundação

\begin{abstract}
Sporting Clube de Braga (SC Braga) is one of the most important Portuguese clubs, officially celebrating its centenary in 2021. The date of its founding, however, is an issue not fully resolved, as there are doubts about when the club was actually created. This article addresses the issue of the foundation of SC Braga, bringing to the discussion new data and documents that allow us to consider that the club was founded on March 20, 1919 and constituted on February 19, 1921.
\end{abstract}

\section{Keywords}

Sports, History, Football, Braga, Sporting Clube de Braga, Foundation

\section{Contact author}

João M. Fernandes

Dep. Informática, Universidade do Minho

Braga, Portugal

jmf@di.uminho.pt

(iD) 0000-0003-1174-1966

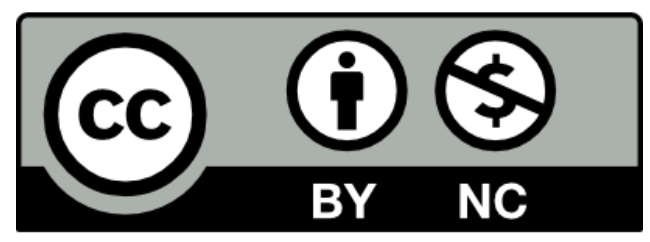

This paper is licensed under a Creative Commons Attribution 4.0 International License. 


\section{Introdução}

A prática desportiva em Braga começou a ganhar alguma visibilidade no início do séc. XX. O Grupo Velocipédico de Braga terá sido o primeiro clube desportivo sedeado em Braga, tendo existido entre 1899 e 1905 para promover a prática do ciclismo. ${ }^{1} \mathrm{O}$ ciclismo foi uma modalidade desportiva muito popular em Portugal, tendo as primeiras competições ocorrido em $1878 .^{2}$ Renato Feio aponta "aí por volta de 1910 " para o início da prática do futebol na cidade de Braga. ${ }^{3}$ O interesse da população de Braga pelo desporto, em geral, e pelo futebol, em particular, só ganharia expressão visível nas décadas de 1910 e 1920 . Nesse período, surgiram vários clubes, a saber: Foot-Ball Club de Braga ${ }^{4}$ (1913), Estrela Foot-Ball Club ${ }^{5}$ (1913), Minho Sport Clube (1914), Grupo Desportivo da Juventude Operária (1916 ou antes), Liberdade Foot-Ball Club (1916), Maximinos Futebol Club (1916), Comércio Sport Club ${ }^{6}$ (1919), Escola Comercial Sport Club ${ }^{7}$ (1919), Estrela Sport Club ${ }^{8}$ (1919), Grupo Desportivo da Juventude Católica (1920), Braga Sport Clube (1921), Boavista Sport Club (1922), Bracarense Sport Club (1922), Bristol Sport Club ${ }^{9}$ (1925), Comercial Foot-Ball Club (1925), Soarense Sport Clube ${ }^{10}$ (1926), entre outros.

Foi neste período que apareceu o SC Braga, cuja data de fundação é um tema não totalmente resolvido. Esta artigo discute as alternativas que podem ser consideradas para data fundacional do clube, partindo de três datas possíveis: 19 de janeiro de 1921, 20 de março de 1919 e 16 de setembro de 1914.

$\mathrm{O}$ artigo encontra-se estruturado da seguinte forma. Na secção 2, discute-se a diferença entre os termos "fundação" e "constituição". As secções 3, 4 e 5 apresentam, cada uma delas, os méritos e deméritos das três datas possíveis para fundação do SC Braga. Na secção 6 são discutidas as três datas alternativas, permitindo na secção 7 apresentar as grandes conclusões deste artigo.

\section{Fundação e constituição de um clube desportivo}

A primeira grande questão que este artigo pretende debater é o que é a fundação duma instituição e mais particularmente de um clube desportivo. Os critérios que definem a fundação são normalmente subjetivos, pelo que pode optar-se por uma de entre muitas datas alternativas ligadas à criação, à organização e ao desenvolvimento dum clube desportivo (ou de qualquer instituição). Cada clube utiliza assim uma data que considera simbólica. Habitualmente, a data de fundação é o dia em que um grupo de pessoas se juntou e decidiu fundar o clube, mas há também outras alternativas possíveis como o dia da primeira assembleia geral, o dia do primeiro jogo, etc. Cada clube é fundado em circunstâncias distintas, pelo que não é possível, nem por ventura recomendável, utilizar-se um critério universal para identificar datas de fundação.

Ainda assim, convém aqui distinguir os termos "fundação" e "constituição". A fundação está ligada à criação ou início de uma qualquer coisa, i.e., é o ato ou efeito de fundar. O termo fundação, aplicado a um clube desportivo, remete para a origem e o princípio do processo de criação desse clube, como pode ser consultado em diversos dicionários:

"1. criação ou início de uma coisa; acto ou efeito de fundar. O mesmo que origem, princípio". ${ }^{11}$

"1 ato ou efeito de fundar, de instituir". ${ }^{12}$

"1 ato ou efeito de fundar 2 origem; princípio". ${ }^{13}$

"Acção ou efeito de fundar, de instituir; princípio, origem de qualquer coisa". ${ }^{14}$

\footnotetext{
1 "Correio do Minho", 18 de janeiro de 1950.

${ }^{2}$ Moreira, G. (1980). A história do ciclismo português. [edição do autor], Alcobaça, p. 17.

3 "Diário do Minho", 4 de fevereiro de 1977.

${ }^{4}$ Foi refundado em 1936, com a designação de Futebol Clube de Braga; ambos eram filiais do FC Porto.

${ }^{5}$ Mudou de designação para Sport Lisboa e Braga e assumiu-se como filial do Benfica, em 1914.

"Mudou de designação para Braga Sport Clube em 1921; “O Lusitano", 6 de janeiro de 1921, "Os Sports”, 13 de janeiro de 1921, “O Sport de Lisboa”, 15 de janeiro de 1921.

7 "Os Sports", 18 de dezembro de 1919.

${ }^{8}$ Ver notícia sobre 13.o aniversário in "Correio do Minho", 31 de dezembro de 1931.

9 "O Lusitano", 21 de novembro de 1925.

${ }^{10}$ A revista "Desportiva", 1 de maio de 1925, faz referência a um jogo entre o Invencível e o Soarense, pelo que este poderá ter existência anterior a 1926.

${ }^{11} \mathrm{~s} / \mathrm{a}$ (2001). Dicionário da língua portuguesa contemporânea, Academia de Ciências de Lisboa, Verbo, Lisboa, vol. I, p. 1835.

${ }^{12} \mathrm{~s} / \mathrm{a}$ (2011). Dicionário do português atual Houaiss, Círculo de Leitores, Lisboa, p. 1168.

${ }^{13} \mathrm{~s} / \mathrm{a}$ (2013). Dicionário da língua portuguesa, Porto Editora, Porto, p. 771.

${ }^{14}$ Silva A. M. (1990). Novo dicionário compacto da língua portuguesa, 6. edição, Editorial Confluência, Lisboa, vol. III, p. 94.
} 
"Acto ou efeito de fundar". ${ }^{15}$

O termo constituição está ligado a questões mais legais e formais. A constituição de um clube desportivo tem assim relação com a formalização do clube junto de entidades oficiais (governamentais, camarárias, desportivas, associativas, etc.).

"Acção ou efeito de constituir || Conjunto dos elementos essenciais, preceitos ou leis por que se regula uma instituição". ${ }^{16}$

"Acto de constituir, de estabelecer. Conjunto de preceitos por que se regula uma instituição, corporação, etc. Estatuto". ${ }^{17}$

O Ministério da Administração Interna detém documentação oficial relativa a vários clubes desportivos, nomeadamente o registo dos seus estatutos. Nesses documentos, são distinguidas precisamente duas datas: data de fundação e data da constituição. Por exemplo, a documentação relativa ao SC Vianense refere 13 de março de 1898 como a data de fundação e 2 de dezembro de 1902 como a data da constituição. ${ }^{18}$ Esta última data corresponde à formalização dos estatutos junto do Governo Civil, como se pode confirmar na secção 2.2.

Este intervalo de tempo entre a criação/fundação de um clube desportivo e a sua formalização/constituição é normal, já que são muitos os trâmites a ultrapassar. $O$ intervalo será tendencialmente maior, quanto maior for a informalidade em que esse clube se movimenta.

De facto, à data, a prática desportiva era essencialmente informal. Segundo Serrado e Serra, ${ }^{19}$ existiam dois tipos de abordagem ao futebol nos primórdios da modalidade em território nacional: futebol organizado e futebol espontâneo. Este último é um jogo informal, sem uma base organizativa e com fins essencialmente recreativos, que não obriga à aplicação estrita e rigorosa de todas as regras do futebol. Contudo, obedece no essencial aos princípios básicos do futebol, ou seja, duas equipas, num terreno de jogo tendencialmente rectangular e plano, a disputar uma bola, sem usar os braços, com o objetivo de marcar golos na baliza adversária.

As diferentes possibilidades para a fundação de um clube são uma dificuldade acrescida. Estabelecer essa data é uma questão subjetiva que, em muitos casos, não permite uma resposta final inequívoca e de agrado de todos. Apresenta-se nas subsecções seguintes, para 35 clubes portugueses, a respetiva data de fundação oficial e que momento cada um deles escolheu para a definir. Para os 30 clubes cuja fundação tem uma efeméride conhecida, 18 deles usam a realização de reuniões (ou assembleias), algumas delas com caráter informal e preparatório. Vêse ainda que nas fusões (Benfica, Oriental, Varzim), a abordagem para definir a data de fundação também varia, o que confirma a ideia que este é uma tema subjetivo, sem regras bem definidas, e que cada caso é um caso.

\subsection{Fusões}

Atlético Clube de Portugal: 18 de setembro de 1942: Fusão do Carcavelinhos FC e do União Lisboa. ${ }^{20}$ Clube Oriental de Lisboa: 8 de agosto de 1946: Assembleia magna dos três clubes, Chelas (fundado em 1911), Fósforos (1920) e Marvilense (1920), que se fundiram para dar origem ao Oriental. ${ }^{21}$

Grupo Desportivo de Chaves: 27 de setembro de 1949: Fusão do Atlético Clube Flaviense e Flávia Sport Clube, após este ter conquistado o acesso à III divisão nacional. ${ }^{22}$

Leixões Sport Club: 18 de novembro de 1907: Reunião em que foi eleita uma comissão para tratar da fusão dos três clubes (Grupo Lawn-Tennis Prado, Grupo Lawn-Tennis de Matosinhos, Grupo Leixões Foot-Ballers) que deram origem ao Leixões. No dia 8 de janeiro de 1908, realizou-se a assembleia geral para eleição dos primeiros corpos gerentes e aprovação dos estatutos, que seriam aprovados pelo governador civil do Porto em 20 de agosto de

\footnotetext{
${ }^{15}$ Figueiredo C. (1991). Dicionário da língua portuguesa, 24. a edição, Bertrand Editora, Lisboa, vol. I, p. 1260

${ }^{16}$ Silva A. M. (1990). Novo dicionário compacto da língua portuguesa, 6.a edição, Editorial Confluência, Lisboa, vol. II, p. 117.

${ }^{17}$ Figueiredo C. (1991). Dicionário da língua portuguesa, 24. a edição, Bertrand Editora, Lisboa., vol. I, p. 708

${ }^{18}$ Ver processo PT/SGMAI/GCVCT/H-B/001/00813 em http://agc.sg.mai.gov.pt/details?id=403583.

${ }^{19}$ Serrado, R. e Serra, P. (2014). História do futebol português: Uma análise social e cultural. Prime Books, Lisboa, vol. 1, pp. 49-57.

${ }^{20}$ Coelho, J. N. e Pinheiro, F. (2002). A paixão do povo: História do futebol em Portugal. Afrontamento, Porto, p. 235.

${ }^{21}$ Figueiredo, V. (2013). Clube Oriental de Lisboa: Histórias do nosso clube. Clube Oriental de Lisboa, Lisboa, p. 11.

${ }^{22}$ Coelho, J. N. e Pinheiro, F. (2002). A paixão do povo: História do futebol em Portugal. Afrontamento, Porto, p. 597.
} 
1908. $^{23}$

Sport Algés e Dafundo: 19 de junho de 1915: Reunião em que se decidiu a fusão do Sporting Clube Dafundo (criado em 1913) com o Algés Football Clube.

Varzim Sport Clube: 25 de dezembro de 1915: Absorção do União FC (que se extinguiu) pelo Varzim Foot-Ball Club, que viria três meses depois a mudar para a sua designação atual. Até 1923, não era claro qual a data fundacional, pois alguns consideravam ser 23 de março de 1916, dia em que se realizou a assembleia geral para aprovar os estatutos e assumir a nova designação. ${ }^{24} \mathrm{Em}$ junho de 1923, os novos estatutos aprovados acabaram por resolver esta questão, considerando que o clube foi "fundado em 25 de dezembro de 1915 e inaugurado em 23 de março de 1916."

\subsection{Reunião / Assembleia}

Associação Desportiva Sanjoanense: 25 de fevereiro de 1924: Reunião magna para se fundar oficialmente um clube desportivo. $^{25}$

Associação Desportiva Limianos: 5 de janeiro de 1953: Reunião para organizar uma comissão fundadora. Os estatutos do clube só foram aprovados por despacho ministerial de 23 de abril de $1953 .^{26}$

Casa Pia Atlético Clube: 14 de junho de 1920: Reunião em que se resolveu fundar um clube constituído apenas por ex-alunos da Casa Pia de Lisboa. ${ }^{27}$

Clube de Futebol Estrela da Amadora: 22 de janeiro de 1932: Reunião em que um grupo de sete jovens decidiu criar um clube de futebol, denominado Estrela da Amadora Futebol Clube. ${ }^{28}$ O clube só seria formalizado no dia 9 de janeiro de 1940 já com a sua designação definitiva.

Clube de Futebol "Os Belenenses": 23 de setembro de 1919: Reunião em que finalmente se decidiu criar um clube de futebol. Esta reunião foi realizada na lisboeta praça Afonso de Albuquerque, junto a um banco de jardim e foi o culminar de uma série de reuniões preparatórias, iniciada em agosto de $1919 .^{29}$

Clube Futebol Benfica: 23 de março de 1933: Assembleia proposta por uma comissão para reorganizar o Grupo Futebol Benfica, de que resultaria a criação do clube. ${ }^{30}$

Futebol Clube Barreirense: 11 de abril de 1911: Assembleia geral do Sport Recreativo Operário Barreirense em que se decidiu a extinção deste e o nascimento dum novo clube. ${ }^{31}$

Gil Vicente Futebol Clube: 3 de maio de 1924: Decisão, tomada por um grupo de jovens, para formar um novo clube de futebol.

Lusitano Ginásio Clube (Évora): 11 de novembro de 1911: Reunião, entre estudantes e marçanos, para criar um clube de futebol. A data de fundação foi escolhida a dedo, já que nos lembra que o futebol é disputado por equipas com 11 elementos.

Portimonense Sporting Clube: 14 de agosto de 1914: Decisão, tomada por um grupo de amigos, em formar um clube que só em 1925, ou seja mais de uma década depois de ter sido fundado, é que submeteu os seus estatutos para aprovação do Governo Civil. ${ }^{32}$

Silves Futebol Clube: 4 de abril de 1919: Decisão, tomada por um grupo de pessoas, para formar um clube. ${ }^{33}$ Sport Clube Vianense: 13 de março de 1898: Reunião para discutir acerca da organização do clube e para discutir o projeto dos estatutos, que seriam aprovados no dia 2 de dezembro de 1902 por alvará do Governo Civil de

\footnotetext{
${ }^{23}$ Galego, B. E. (2001). Leixões Sport Club: Marcos importantes da sua história (1907/2000). Editorial Maresia, pp. 16, 21.

${ }^{24}$ Vila Cova, A. (2010). Varzim S.C.: Orgulho de um povo. Póvoa de Varzim, p. 17.

${ }^{25}$ Neto, D. e Silva, P. (1999). Associação Desportiva Sanjoanense: 75 anos de história (1924-1999). Laborpress, São João da Madeira, pp. 16-17.

${ }^{26}$ Gonçalves, J. C. (2013). "Os Limianos" e a história do futebol em Ponte de Lima. Câmara Municipal de Ponte de Lima, Ponte Lima, p. 38-39.

${ }^{27}$ Pinto, J. S. e Tavares, H. (1990). Casa Pia Atlético Clube (Ateneu Casapiano). Biblioteca-Museu Luz Soriano, Lisboa, p. 31.

${ }^{28}$ Coelho, J. N. e Pinheiro, F. (2002). A paixão do povo: História do futebol em Portugal. Afrontamento, Porto, p. 613.

${ }^{29}$ Ceitil, J. (2009). Clube de Futebol Os Belenenses: 90 anos de história. Âncora Editora, Lisboa, pp. 31-32.

${ }^{30}$ Estanislau, D. (1993). História do Clube Futebol Benfica. Clube Futebol Benfica, Lisboa, pp. 41-42.

${ }^{31}$ Figueiredo, J. R. (1986). 70 anos de vida do Futebol Clube Barreirense, p. 16.

${ }^{32}$ Alves, A. (2003). Portimonense Sporting Clube: 89 anos de história, 1914-2003. Portimonense Sporting Clube, Portimão, pp. 10-12.

${ }^{33}$ Alves, A. (1993). Silves Futebol Clube: 74 anos de história. AA Publicações / Silves Futebol Clube, Loulé, p. 15.
} 
Viana do Castelo. ${ }^{34}$

Sport Lisboa e Benfica: 28 de fevereiro de 1904: Reunião rápida (para não se perder tempo com burocracias), realizada após um treino entre jogadores, em que se decidiu fundar o Sport Lisboa. ${ }^{35}$ Este clube daria origem, em 1908, ao SL Benfica, por fusão com o Grupo Sport Benfica. ${ }^{36}$ Assim, o Benfica, com a sua designação atual, nasceu em 1908, mas o clube (i.e., as pessoas, o símbolo e os seus jogadores) já existia desde 1904. Os primeiros estatutos só seriam redigidos em 1912. Até aí, havia normas incluídas em atas de assembleias gerais.

Sporting Clube de Portugal: 1 de julho de 1906: Assembleia geral que aprovou a alteração do nome do clube para Sporting Clube de Portugal, que assim deixou de se designar Campo Grande Sporting Clube (designação adoptada cerca de um mês antes). No dia 1 de maio de 1920, em assembleia geral, decidiu-se a mudança da data oficial de fundação de 8 de maio de 1906 para 1 de julho do mesmo ano, com a justificação que foi neste dia que o clube tomou o seu nome atual. Dias considera o 1.ㅇ de julho com uma data convencional (e não exata) e sugere que a data de fundação seja 8 de maio de 1906, que foi quando se constitui a primeira direção. ${ }^{37}$ Os estatutos foram enviados para o Governo Civil de Lisboa a 19 de Julho de 1907 e aprovados a 22 de Agosto de $1907 .^{38}$

Sporting Clube Olhanense: 17 de abril de 1912: Reunião entre jogadores para criar o clube, tendo-se decidido o nome e os equipamentos a usar. ${ }^{39}$

União Futebol Comércio e Indústria de Tomar: 4 de maio de 1914: Reunião em que se deliberou a criação de um clube dedicado ao futebol. ${ }^{40}$

Vitória Futebol Clube (Setúbal): 10 de novembro de 1910: Decisão, tomada por três membros do Bonfim Futebol Clube, à época um dos mais populares clubes de Setúbal, para fundar o Sport Vitória. A 5 de maio de 1911, realizou-se a primeira assembleia geral, em que se alterou a denominação para Vitória Futebol Clube. A data de fundação do clube está indicada no emblema.

Vitória Sport Clube (Guimarães): setembro de 1922: Agrupamento de pessoas para formar o clube. ${ }^{41}$

\subsection{Outros}

Académico Futebol Clube (Porto): 15 de setembro de 1911: Decisão de criar um clube desportivo por iniciativa de José Neves, na altura um rapaz de 14 anos. Este clube viveu sem um nome definido durante cerca de três anos e só oficializaria a sua existência a 13 de fevereiro de 1915, dia em que os estatutos do clube foram enviados para o governo civil do Porto. ${ }^{42}$

Aliados Futebol Clube de Lordelo: 28 de maio de 1950: Jogo amigável entre o Balselhense e uma equipa de Lordelo. Para evitar uma derrota copiosa, procurou-se incluir jogadores de Lordelo de baixo e de cima, criando-se assim um clube que fundia ambas as partes. ${ }^{43}$

Clube Desportivo Nacional: 8 de dezembro de 1910: Apresentação, após um jogo de futebol, da ideia da criação do Nacional Sport Grupo que viria posteriormente (1916) a assumir a designação atual. ${ }^{44}$

Futebol Clube do Porto: 28 de setembro de 1893: Publicação no jornal "Diario Illustrado" de uma notícia que revela ter sido fundado um clube denominado Football Club do Porto. ${ }^{45} \mathrm{Em} \mathrm{1988,} \mathrm{os} \mathrm{sócios} \mathrm{do} \mathrm{clube} \mathrm{portista}$

\footnotetext{
${ }^{34}$ Viana, R. A. F., Peixoto, A. M., e Silva, P. P. (1998). S. C. Vianense: 100 anos de história em datas (1898-1998). Sport Clube Vianense, Viana do Castelo, pp. 11, 21.

${ }^{35}$ Barreto, A. e Mónica, M. F. (1999). Dicionário de história de Portugal. Livraria Figueirinhas, Lisboa, vol. IX, pp. 479-480; Serrado, R. (2010). Cosme Damião: O homem que sonhou o Benfica. Zebra Publicações, Lisboa.

${ }^{36}$ Serrado, R. e Serra, P. (2014). História do futebol português: Uma análise social e cultural. Prime Books, Lisboa, vol. 1.

${ }^{37}$ Dias, M. T. (2005). Sporting Clube de Portugal: Uma história diferente. Fubu Editores, Porto, p. 55.

${ }^{38} \mathrm{O}$ documento original está atualmente na Torre do Tombo; Ver processo PT/SGMAI/GCLSB/H-B/001/00832 em http://agc.sg.mai.gov.pt/details?id=574140.

${ }^{39}$ Alves, A. (2012). Sporting Clube Olhanense: Honra e glória. Sporting Clube Olhanense, Olhão, p. 27.

${ }^{40}$ Vicente, L. (2014). União de Tomar: 100 anos de história [1914-2014]. Tomar, p. 279.

${ }^{41}$ Machado, M. e Lobo, A. (1997). Vitória Sport Clube: 75.o aniversário. Vitória Sport Clube, Guimarães, p. 19.

${ }^{42}$ Pacheco, H. (2011). Académico Futebol Clube: Um século na vida portuense, ao serviço do desporto. Afrontamento, Porto, pp. 65-66.

${ }^{43}$ Silva, J. B. P. (2000). Aliados Futebol Clube de Lordelo. Anégia Editores, Lordelo, pp. 37-38.

${ }^{44}$ Nóbrega, T. (2010). Nacional 1910-2010: Álbum do centenário. Clube Desportivo Nacional, Funchal, p. 8.

${ }^{45}$ Barreto, A. e Mónica, M. F. (1999). Dicionário de história de Portugal. Livraria Figueirinhas, Lisboa, vol. VIII, p. 78 ; Serrado, R. e Serra, P. (2014). História do futebol português: Uma análise social e cultural. Prime Books, Lisboa, vol. 1, p. 97.
} 
aprovaram esta como a data da sua fundação, em vez do dia 2 de agosto de 1906, que tinha sido usada até então. Sertanense Futebol Clube: 11 de março de 1934: Festa de inauguração do clube. A primeira direção do clube decidiu usar esta efeméride para marcar a sua fundação, mas, ao longo de vários anos, verificou-se que a data coincidia com a Quaresma, o que impedia a realização de vários tipos de festas. Assim, o clube decidiu passar a usar como data de fundação o dia 17 de fevereiro de 1934, que foi quando o Governo Civil de Castelo Branco promulgou os estatutos e emitiu o alvará de funcionamento. A escolha desta data foi feita apenas por conveniência para permitir comemorar de forma menos restritiva os aniversários do clube. ${ }^{46}$

Sporting Clube da Covilhã: 2 de junho de 1923: Oficialização do estatuto de (8. ${ }^{\text {a }}$ filial do Sporting por parte do presidente deste clube. $^{47}$

\subsection{Desconhecido}

Clube Desportivo Feirense: 18 de março de 1918: Fundação (sem indicação da efeméride) da Associação Desportiva Feirense que viria em 1926 a alterar a sua designação para a atual. ${ }^{48}$ Há contudo uma segunda versão que aponta a data de fundação como sendo um dia mais tarde. Contudo, o Feirense só em 1924 realizou o seu primeiro jogo de futebol e elegeu os seus primeiros órgãos sociais. ${ }^{49}$

Club Sport Marítimo: 20 de setembro de 1910: Data assumida como oficial pelo clube, apesar de o primeiro jogo se ter realizado umas três ou quatro semanas antes. ${ }^{50}$ É uma data algo incerta, pelo que foi estabelecida por aproximação.

Futebol Clube de Felgueiras: maio de 1932: Fundação (sem indicação da efeméride) do Santa Quitéria FC que viria, em 17 de outubro de 1932, a alterar a sua designação FC Felgueiras. Todavia, o Felgueiras só em 1953 é que oficializou a sua existência, através de escritura pública e publicação no então Diário do Governo. ${ }^{51}$

Lusitano Futebol Clube (Vila Real de Santo António): 15 de abril de 1916: Não existem documentos que suportem esta data. O mais antigo documento conhecido, referente ao Lusitano, está datado de 19 de junho de 1916 e é um pedido feito pelo clube à câmara municipal para se poder treinar numa avenida da cidade. ${ }^{52}$

Moreirense Futebol Clube: novembro de 1938: Não é conhecido com exatidão o dia em que o clube foi fundado. Contudo, há relatos da existência dum jogo de futebol onde intervém o Moreirense em 27 de junho de 1938 , ou seja, cerca de quatro meses antes da fundação. ${ }^{53}$ Os estatutos só foram aprovados, por despacho ministerial, em 1946.

\section{Fundação em 1921}

Oficialmente, o SC Braga considera como data de fundação o dia 19 de janeiro de 1921, facto que está aliás plasmado nos estatutos mais recentes do clube, designadamente no ponto 1 do art.o 1 ‥ Esta é supostamente a data em que os estatutos do clube foram submetidos para aprovação do Governo Civil de Braga (Fig. 1). 0 SC Braga legalizava assim a sua existência ao abrigo da lei de 14 de fevereiro de 1907, que estabelecia o direito de associação. Esta lei permitia aos cidadãos que constituíssem associações, sem dependência de licença ou aprovação dos seus estatutos pela autoridade pública, desde que participassem previamente ao governador civil a sede, o fim e o regime interno da sua associação.

O termo "supostamente" foi acima usado, pois a comunicação escrita feita ao Governo Civil está claramente datada de 19 de fevereiro de 1921, mas, por motivo desconhecido, a data foi fixada um mês antes. Uma possível

\footnotetext{
${ }^{46}$ Lopes, R. P. (2009). Sertanense: 75 anos de história (1934-2009). Câmara Municipal da Sertã, Sertã, pp. $14-15$.

${ }^{47}$ Nunes, J. J. (1993). Figuras e factos do Sporting Clube da Covilhã. Sporting Clube da Covilhã, Covilhã, p. 20.

${ }^{48}$ Higino, L. F. (2003). Clube Desportivo Feirense: Breve história cronológica (85 anos, 1918-2003). Clube Desportivo Feirense, Santa Maria da Feira, pp. 10-11.

${ }^{49}$ Maia, R., Higino, L. F., Brandão, A., e Santos, G. (2010). Memórias avulsas de Rui Maia: 50. aniversário da geração de ouro de 1960 do Clube Desportivo Feirense. Clube Desportivo Feirense, Santa Maria da Feira, p. 10.

${ }^{50}$ Bragaglia, P. (1996). Club Sport Marítimo: 85 anos de história. Club Sport Marítimo, Ponta Delgada, pp. 15-16.

${ }^{51}$ Pinto, A. (2007). Futebol de Felgueiras - nas fintas do tempo: 1932/2007. [edição do autor], Felgueiras, p. 9.

${ }^{52}$ Cavaco, H. (1991). Luzitano Foot-ball Club (1916/1991): “Origens - Percurso - Actualidade”. Câmara Municipal de Vila Real de Santo António, Vila Real de Santo António, p. 9; Cavaco, H. (2002). Lusitano Futebol Clube: Arca de memórias. Câmara Municipal de Vila Real de Santo António, Vila Real de Santo António, pp. 13-14.

${ }^{53}$ Bernardino, A. e Machado, P. (2013). Moreirense FC - 1938/2013: Trabalho, dedicação, história. Moreirense Futebol Clube, Moreira de Cónegos, p. 14.
} 
explicação para este erro está relacionada com o facto de 'Fevereiro' estar escrito por extenso e com letra manuscrita, nomeadamente com um ' $F$ ' muito curvilíneo. Assim, é possível que alguém tenha erradamente lido janeiro e que, durante bastante tempo, ninguém tenha voltado a analisar o documento original e o erro foi permanecendo. Uma outra explicação sustenta-se na ideia que esses estatutos estão datados de 19 de janeiro de 1921 e que só um mês mais tarde foram apresentados ao governador civil do distrito. ${ }^{54} \mathrm{~A}$ impossibilidade de localizar o documento original desses estatutos contudo não permite confirmar esta hipótese.

A comunicação enviada ao Governo Civil indica o seguinte: "Os abaixo assinados tem a honra de participar a V.Ex. ${ }^{\text {a }}$ (...) que no prazo de três dias principiará a funcionar (...) um clube denominado "Sporting Club de Braga" (...)" Numa leitura estritamente legal, o SC Braga iniciou oficialmente as suas atividades três dias após a data indicada na comunicação. Pensamos, contudo, que é aceitável usar o dia 19 de fevereiro de 1921 como data da constituição do clube, de acordo com a definição dada na secção 2.

Há muitos clubes portugueses que só aprovaram/oficializaram os seus primeiros estatutos (i.e., procederam à sua constituição) depois da respetiva fundação. Isto é perfeitamente razoável, pois os estatutos constituem as normas ou o regulamento de uma instituição. A realização de uma reunião ou assembleia geral parece ser o critério predominante que os clubes desportivos portugueses usam para estabelecer a sua data de fundação. De facto, nenhum dos clubes portugueses indicados na secção 2 usa a formalização dos estatutos para esse efeito. Para alguns deles (Ac. Porto, Benfica, Estrela da Amadora, Felgueiras, Leixões, Limianos, Moreirense, Portimonense, Sporting, Varzim) é referido que os estatutos só foram aprovados após a fundação. Mesmo clubes fundados mais tarde seguem este padrão dos estatutos serem posteriores à sua fundação. O Club Foot-Ball Os Bracarenses, por exemplo, foi fundado em 22 de dezembro de 1935, data que aparece nos estatutos que submeteu para aprovação do Governo Civil no dia 25 de julho de $1936 .{ }^{55}$ O Estoril Praia foi fundado a 17 de maio de 1939 e os seus estatutos aprovados três semanas depois (7 de junho de 1939). O FC Penafiel foi fundado no dia 8 de fevereiro de 1951 e os seus estatutos aprovados a 20 de março do mesmo ano. ${ }^{56}$

\footnotetext{
${ }^{54}$ Sporting Clube de Braga (1996). 75 anos de alma e coração: 1921-1996. Revista comemorativa dos 75 anos do clube, p. 12.

${ }^{55} \mathrm{O}$ documento original está atualmente no Arquivo Distrital de Braga.

${ }^{56}$ Ferreira J. F. C. (1996). História do Futebol Clube de Penafiel fundado em 8-2-1951 e antigos clubes penafidelenses. Futebol Clube de Penafiel, Penafiel, p. 81.
} 


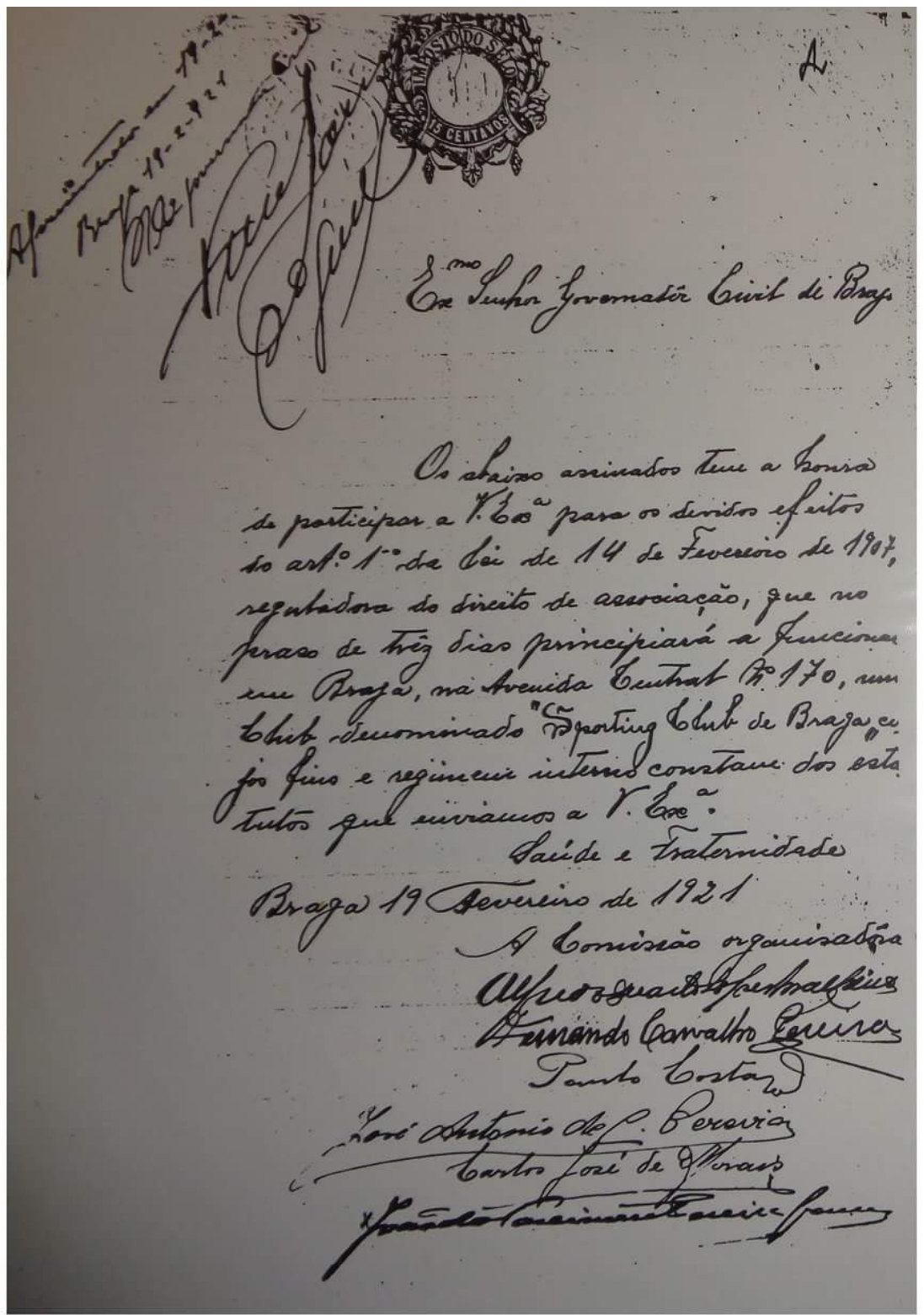

Figura 1 - Carta enviada ao Governo Civil de Braga para legalização do SC Braga.

A A.F. Braga só viria a ser constituída em novembro de 1922, sendo que o SC Braga foi precisamente um dos fundadores da associação distrital, com o objetivo de dar caráter oficial e regular à prática do futebol na cidade (e no distrito) de Braga. Antes da criação da associação distrital, o SC Braga estava limitado à prática do futebol espontâneo e não tinha qualquer vantagem ou benefício em formalizar e legalizar a sua existência.

A maioria dos clubes indica no artigo 1. dos seus estatutos a sua data de fundação. A primeira versão dos estatutos do SC Braga não faz infelizmente essa indicação. ${ }^{57}$ A segunda versão, aprovada em assembleia geral realizada a 21 de fevereiro de $1925,{ }^{58}$ também não refere a data de fundação. Só mais tarde, passou a ser prática comum os estatutos dos clubes fazerem essa referência. Assim algures no tempo, alguém sentiu a necessidade de indicar a data de fundação, durante alguma revisão dos estatutos do SC Braga, para o documento seguir o formato típico. Não foi possível identificar quando é que esta data passou a constar dos estatutos. A primeira referência escrita que se encontrou a 19 de janeiro de 1921, como sendo o da fundação do SC Braga, foi na cópia

\footnotetext{
${ }^{57}$ Barros Pereira, J. E. (1985). Sporting Clube de Braga 1921-1985. Correio do Minho, Braga, pp. 15-26.

58 "O Lusitano", 20 de fevereiro de 1925.
} 
dos estatutos do clube incluída nas atas da direção do clube (reunião 23 de março de 1954). ${ }^{59}$ Não se conhecendo o processo que levou à alteração dos estatutos, aventa-se a hipótese de ter sido usada a data do documento formal mais antigo que se encontrou (i.e., a tal comunicação ao Governo Civil). Em qualquer caso, não parece que o estabelecimento da data de fundação tenha sido um processo feito com o rigor e o cuidado que eram exigidos. É sabido que o SC Braga mudou algumas vezes de sede e que nessas mudanças se perderam documentos. Celestino Lobo confirma esta informação e indica que, entre 1927 e 1931, "os livros e as taças do clube (...) passaram a andar pelas casas dos directores. Os livros vieram a desaparecer, as taças (...) apareceram todas". 60

\section{Fundação em 1919}

$\mathrm{Na}$ ausência de uma ata de fundação, deve analisar-se os documentos que estão disponíveis e identificar qual o momento (formal ou informal) que corresponde à concretização do desejo de se constituir o SC Braga. Há que identificar o primeiro momento em que ganha forma (oficialmente ou não) o SC Braga, primeiro como um grupo de pessoas com vontade em criar um clube e só depois como clube legalmente constituído.

A descoberta recente duma carta assinada pelo 1. secretário da direção do SC Braga (Manuel Esmeriz), com a indicação explicita do dia $\mathbf{2 0}$ de março de 1919 como sendo a data de fundação é elemento novo que dá força à tese que o clube foi fundado em 1919 (Fig. 2). Essa carta, datada do dia 31 de julho de 1926, faz parte da documentação que a direção do SC Braga submeteu ao Comité Olímpico Português (COP) para requerer o estatuto de utilidade pública. Dessa documentação faz ainda parte uma carta da Câmara Municipal de Braga que atesta que o SC Braga foi organizado em 1919 (Fig. 3). Estes documentos, dado o seu caráter formal, e a sua proximidade temporal (apenas sete anos depois), não deixam grandes dúvidas sobre o ano em que o clube começou as suas atividades. Um artigo publicado no Correio do Minho ${ }^{61}$ indica que, no princípio de 1919 , surgiu a ideia de fundar o SC Braga e acrescenta que no dia 19 de março de 1919 foi constituída a primeira direção do clube. Esta indicação tão precisa (i.e., com dia, mês e ano) é uma raridade em todas as fontes que foram consultados para este propósito e reforça que, passados 30 anos, a data ainda era recordada (no caso com um dia de diferença).

Para além desta documentação, desconhecida até há pouco, há ainda inúmeras evidências que apontam para a existência de iniciativas e atividades do clube antes da data da sua constituição em 1921. Desde logo, cabe referir que, no dia 24 de junho de 1920, o SC Braga disputou o primeiro jogo de futebol da sua história, o que parece inviabilizar uma data fundacional posterior a essa data. Este jogo, noticiado pelo Diário do Minho e pelo "Os Sports", publicado em Lisboa, constitui mais um dado novo, até agora nunca referenciado (ver Fig. 4). Passa a ser outro marco muito relevante na história do clube, contrariando versões anteriores que apontavam o jogo com o Liberdade como tendo sido o primeiro jogo do SC Braga. O oponente foi o Sport Club Caixeiros, que foi derrotado por 4-0. O SC Braga alinhou com Carlos Morais, José Pereira, Fernando Pereira, Gomes, Vieira, Mouta, Eurico Sameiro, Luiz Braga, Vale, Mota e Braga. Muitos destes nomes surgirão intimamente, e de forma relevante, ligados à constituição legal/formal do SC Braga em 1921, como são os casos de Carlos Morais - Carlos José Morais; José Pereira - José António Carvalho Pereira; Gomes - João Nascimento Ferreira Gomes; Fernando Pereira - Fernando Carvalho Pereira, quatro dos seis subscritores do documento entregue com os estatutos no Governo Civil em 1921. Todos estes, e também Eurico Sameiro, fizeram parte dos órgãos sociais do clube que foram eleitos em 10 de Fevereiro de 1921 e de onde emanaram os primeiros estatutos. Este relacionamento "pessoal" entre o SC Braga de 1919 e o de 1921 como que solidifica a ponte que une uma e a mesma entidade.

\footnotetext{
${ }^{59}$ Diário do Governo, n.o 27, III série, 2 de fevereiro de 1954.

60 "Sporting Club de Braga", 23 de janeiro de 1960.

${ }^{61}$ Edição de 28 de maio de 1948.
} 


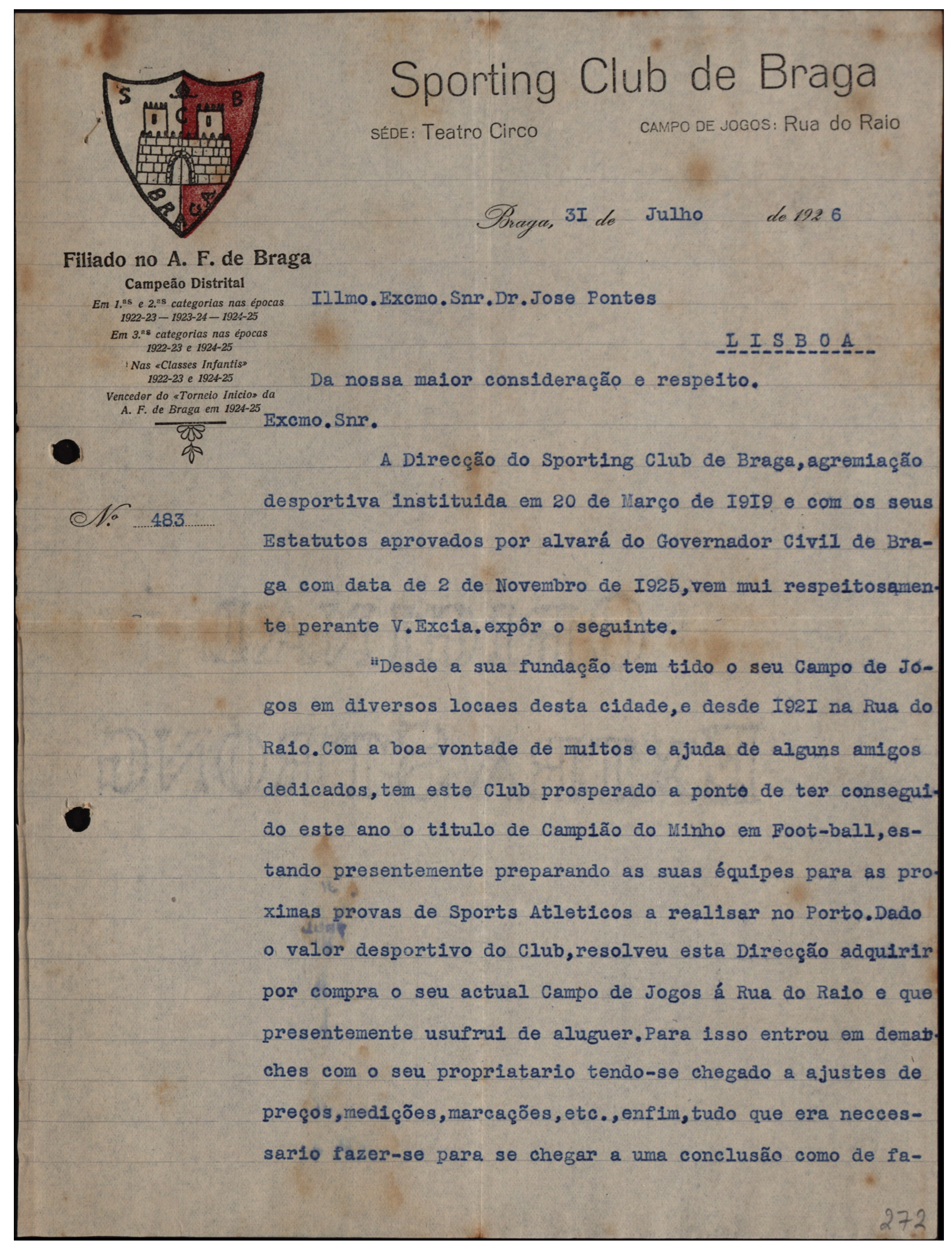

Figura 2 - Parte da carta que o SC Braga enviou em 1926 ao COP para solicitar o estatuto de utilidade pública. (Arquivo COP) 


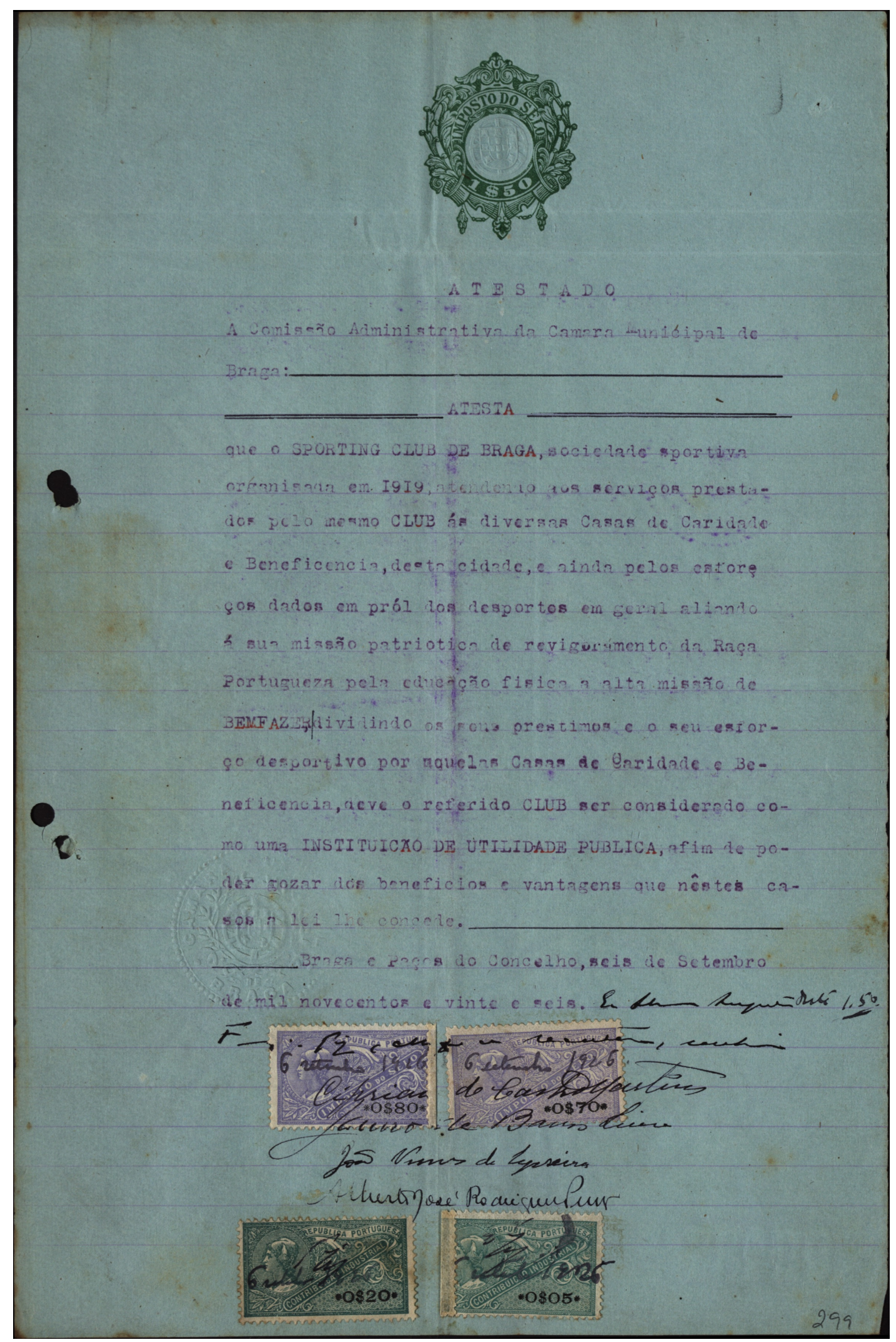

Figura 3 - Atestado da Câmara Municipal de Braga, incluído na documentação que o SC Braga enviou ao COP, que refere que o clube já estava organizado desde 1919. (Arquivo COP) 


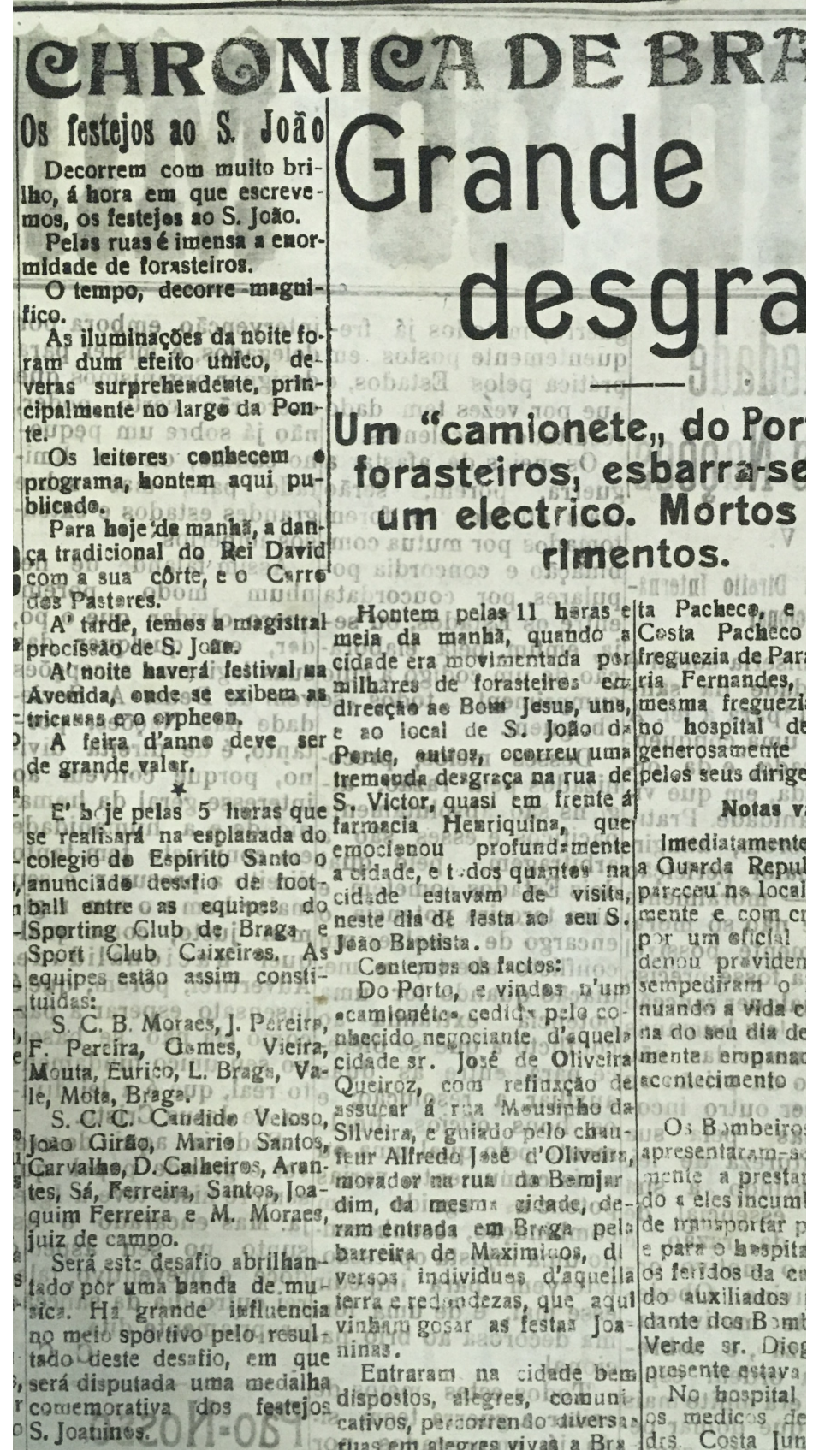

BRAGA.-(Atrazado).-No dia 24 do mez passado realisou-se um desafio de foot-ball entre o Sporting e Caixeiros, vencendo aquele por 4 goals a zero. A assistencia foi grande, recebendo os vencedores medalhas.-C.

Figura 4 - Recortes do "Diário do Minho" (24 de junho de 1920) e de "Os Sports" (1 de julho de 1920), em que se noticia o mais antigo jogo de futebol conhecido do SC Braga. 
Na revista comemorativa dos 15 anos do clube (em 1934), Celestino Lobo, uma figura incontornável da história do SC Braga, numa peça intitulada "Como se fundou o Sporting", escreve o seguinte: "O Sporting (...) nasceu na Arcada. (...) Era numa tarde quente de verão (...) e os rapazes lamentavam não possuirem um recinto onde se pudessem divertir. Alguem alvitrou a constituição dum club. A ideia geminou rapidamente." Portanto, Celestino localiza, sem grandes dúvidas, o verão de 1919 como aquele em que o SC Braga começou a ser organizado. Mesmo mais tarde (1960), aquilo que Celestino escreveu no jornal do clube parece corroborar, sem grandes dúvidas, essa tese: "A Guerra de 1914 tinha terminado. (...) Na Escola Comercial, havia um grupo de rapazes, todos em volta dos 20 anos (...) Reuniram-se e resolveram fundar um grupo de Foot Boll". ${ }^{62}$ Celestino repete esta mensagem, uma década depois depois, quando afirma: "A guerra de 191418 (...) veio a ter nefastas consequências para o futebol da Bracara Augusta. (...) o conflito europeu veio provocar a falência dos dois clubes existentes na capital do Minho [FC Braga e SL Braga]. Aliás todo o futebol parou. Só decorridos 5 longos anos [1919] é que se deu o recomeço da actividade futebolística. E é precisamente dessa renovação que nasce o Sporting Clube de Braga". 63

Carlos Andrade Lobo, filho de Celestino Lobo, diz-nos que "A ideia de criar um clube apareceu por volta de 1918/19, e segundo contava meu pai, pela necessidade de um grupo de jovens de Braga. Só cerca de dois anos mais tarde é que entenderam dar uma maior dimensão ao clube". ${ }^{64}$

Bernardino Gomes escreve, na revista comemorativa dos 16 anos do clube, o seguinte: "Depois da Guerra, surgiu o "Sporting", club de élite e de utilidade pública, considerado". ${ }^{65}$

Reinaldo Bastos, vice-presidente do clube em 1950 e antigo presidente do clube (1932-1933), afirma que o clube foi fundado em 1919. ${ }^{66}$ O quinteto que, no início de 1921, organizou o clube, designado de "comissão organizadora", 67 era composto por Alfredo Malheiro, Paulo Costa, Carlos Morais e os irmãos José e Fernando de Carvalho Pereira. ${ }^{68}$ Estes cinco nomes são confirmados pelo próprio Paulo Costa, a propósito das comemorações das bodas de prata do clube (1919-1944). ${ }^{69}$

Em 1946, uma reportagem da prestigiada revista "Stadium" indicava que "o ideal de há 27 anos mantem-se com toda a pureza de dedicado sentimento clubista que ajudou a erguer o Sporting bracarense". ${ }^{70}$

Em 1947, em comunicado público, a direção do clube, a propósito das acusações de suborno antes do jogo contra o Onze Unidos, refere que o clube tinha à data 28 anos de existência, ou seja, que teria sido fundado em $1919 .{ }^{71}$ Em 1961, em carta enviada ao Governo Civil de Braga, a comissão administrativa do clube refere que o clube tinha à data 40 anos de existência (Fig. 5). Contudo, na transcrição dessa carta na imprensa, essa informação foi "corrigida", alterando-se para 42 anos de existência. ${ }^{72}$ Desconhece-se quem tomou a iniciativa de proceder à alteração, mas a mesma indica claramente que, na altura, já havia duas facções relativamente à data de fundação do clube: 1919 e 1921. Ainda em 1962, na sequência duma assembleia geral, é organizada uma exposição dos troféus ganhos pelo clube "nos seus 43 anos de vida gloriosa". ${ }^{73}$

\footnotetext{
62 "Sporting Club de Braga", 7 de novembro de 1959.

63 "Correio do Minho", 10 de abril de 1969.

${ }^{64}$ Ver entrevista, concedida em 2010, ao site "MaisFutebol" https://maisfutebol.iol.pt/braga-um-sporting-verde-convertidoem-arsenal-do-minho.

${ }^{65}$ Sporting Clube de Braga (1935). Semana desportiva do Sporting: 1919-1935. Revista comemorativa do 16. aniversário do clube.

${ }^{66}$ Ver entrevista publicada na revista "Stadium", 13 de dezembro de 1950.

${ }^{67}$ Este termo consta da comunicação enviada ao Governo Civil em fevereiro de 1921.

68 "O Lusitano", 3 de março de 1921.

69 "Diário do Minho", 28 de março de 1944. A revista "Stadium", 3 de maio de 1944, dá também conta deste facto, com o pequeno erro de referir Carlos Morais como Carmo Morais.

70 "Stadium", 14 de agosto de 1946.

71 "Correio do Minho", 4 de junho de 1947.

72 "A Bola", 3 de junho de 1961.

73 "Correio do Minho", 10 de junho de 1962.
} 


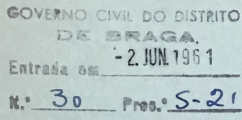

O SPORT DTO CIXI E DE DRAGA, colectividade considerada de utilidade pública, lidimo representorte do despordoderaranse e cartaz gritante de neonacanda turistica da olsua sobrevivenoia, mercê de sacrificios pessoais e materiais de uns tantos bairrietas o que, por vez es, tem sido ingentes.

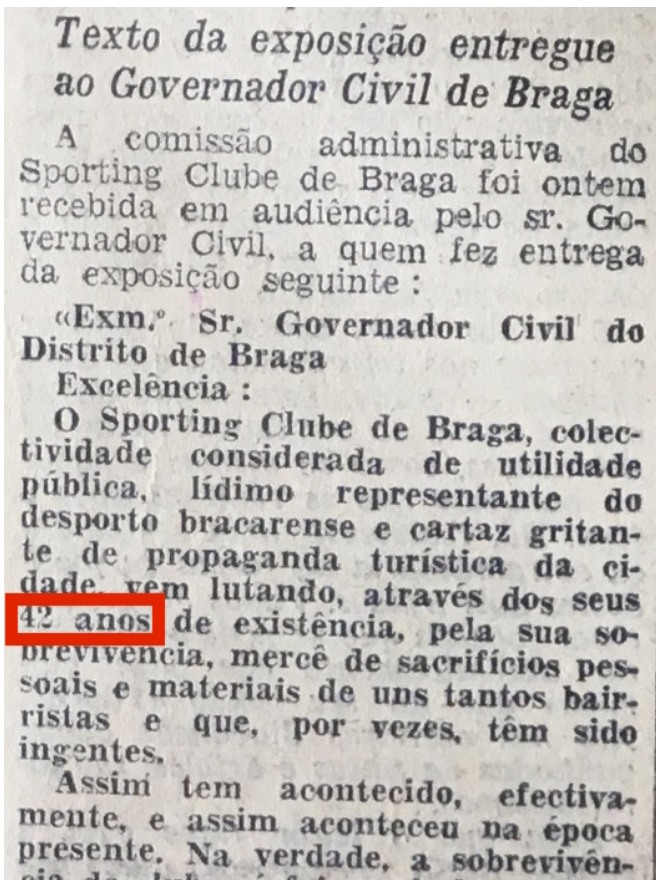

Figura 5 - Carta enviada ao Governo Civil de Braga e respetiva transcrição no jornal "A Bola", 3 de junho de 1961, com uma pequena, mas significativa, alteração face ao original.

Um artigo publicado na revista "Terras de Portugal", numa edição dedicada à inauguração do estádio 28 de maio, indica em relação ao SC Braga que "Desde a sua fundação, há anos, há mais de 30 anos, em Dezembro de 1919". ${ }^{74}$ A revista comemorativa dos 75 anos do clube indica que muitos daqueles que estiveram ligados ao nascimento do clube referem o período entre dezembro de 1919 e o outono de $1920 .^{75}$

Este interregno entre finais de 1919 e inícios de 1921, ou seja entre a fundação do clube e a sua constituição, está também muito claro à luz do que Celestino Lobo escreveu na revista comemorativa dos 15 anos do clube: ${ }^{76}$

"Depois, durante algum tempo o entusiasmo estagnou. (...) O amor próprio renasceu. Marcou-se a data das eleições. Num dia de dezembro (...) vinha a lume a primeira Direcção do atual Sporting. Dois ou três meses depois o seu primeiro grupo batia-se com o Liberdade". Este jogo com o Liberdade foi disputado a 13 de março de 1921, pelo que a primeira direção do clube surgiu em dezembro de 1920 ou janeiro de 1921, a fazer fé nos textos de Celestino Lobo. Poderá haver aqui um pequeno erro, já que a primeira direção do clube foi eleita no dia 10 de fevereiro de $1921,{ }^{77}$ ou então Celestino refere-se ainda a uma direção informal.

Entre os verões de 1919 e 1920, terão existido inúmeros avanços e recuos na constituição do SC Braga. Domingos Luz indica numa crónica que "em Julho ou Agosto de 1920, no antigo Minho Club (ficava na parte sul das Arcadas) (...) realizou-se uma reunião preparatória para a fundação do clube de todos nós" ${ }^{78}$ Essa reunião, presidida por Paulino António da Costa (Lago), serviu para aprovar os estatutos.

Celestino Lobo acrescenta ainda no jornal do clube: "Fui eu e o Paulo Costa encarregados das primeiras

démarches quanto à constituição. Encarreguei-me de elaborar os estatutos (...) A constituição do club iniciado por altura de Setembro [1919] esteve um pouco indecisa (...), mas (...) em Fevereiro ou Março do ano seguinte [1920] constituíam-se os corpos gerentes $\}^{\prime \prime} .^{79}$ Celestino Lobo não indica os anos, mas parece-nos que o setembro a que ele se refere é o de 1919, o que confirma a tese de que o início do clube ocorreu nesse ano. A guerra terminou oficialmente em 11 de novembro de 1918 (Armistício de Compiègne), mas é provável que só um pouco mais tarde

\footnotetext{
74 "Terras de Portugal", maio de 1950.

${ }^{75}$ Sporting Clube de Braga (1996). 75 anos de alma e coração: 1921-1996. Revista comemorativa dos 75 anos do clube, p. 12.

${ }^{76}$ Sporting Clube de Braga (1934). Sporting Clube de Braga: 1919-1934. Revista comemorativa do 15. aniversário do clube.

77 "O Lusitano", 17 de fevereiro de 1921.

78 "Correio do Minho", 15 de maio de 1969.

79 "Sporting Club de Braga", 7 de novembro de 1959.
} 
a população portuguesa começasse a sentir que a paz estava estabelecida.

A imprensa local refere em junho de 1919 que "O desporto parece ressurgir nesta cidade". ${ }^{80}$ Há também uma notícia nesse mesmo jornal e outras duas no Diário do Minho que apontam que, em novembro de 1919, os trabalhos para a criação do SC Braga já estavam avançados e prestes a ser finalizados, reforçando a ideia que se terão iniciado antes. ${ }^{81}$ Em maio e junho de 1920, a imprensa volta a indicar que o SC Braga estava a ser organizado. $^{82}$

As notas de Celestino Lobo, escritas em 1959 e 1960, são muito relevantes para quem quiser estudar a fundação e a história do SC Braga, mas devem ser entendidas com alguma reserva. Essas notas foram feitas 40 anos após a fundação do clube e, em muitas passagens, o autor teve a honestidade intelectual de revelar ter dúvidas ou não se lembrar de alguns aspectos sobre aquilo que escreve. É pois possível que algumas informações,

nomeadamente datas, não estejam totalmente corretas, mas parece-nos que, no essencial, Celestino Lobo narrou com rigor os factos mais relevantes da história do SC Braga e que, em momento algum, omitiu ou alterou propositadamente alguns desses factos.

Os filhos do presidente José Antunes Guimarães apontam 1919 como ano fundacional: "83 "Para nós, o ano da fundação do SCB é 1919, quando o clube de facto se organizou e começou a competir. A data de 1921 corresponde apenas à apresentação (...) dos estatutos no Governo Civil, uma vez que, quer em 1934 quer em 1944, se comemoraram respectivamente os 15 e os 25 anos de existência do clube, sem que isso provocasse qualquer polémica com os fundadores, então ainda vivos."

Efetivamente, até 1944, o SC Braga comemorou os seus aniversários sempre com referência ao ano de 1919. Não parece ter havido grande cuidado ou preocupação com o dia e o mês, mas refira-se que as boas de prata, uma data mais especial que outros aniversários, se iniciaram precisamente no dia 19 de março de 1944, ou seja, na véspera de se comemorarem os 25 anos da fundação do clube.

- 15. o aniversário: 20 a 27 de maio de $1934 .^{84}$

- 16. o aniversário: 26 de maio a 2 de junho de $1935 .^{85}$

- 17. o aniversário: 7 a 14 de junho de $1936 .^{86}$

- 19. o aniversário: 15 de maio de $1938 .^{87}$

- 22.9 aniversário: 4 a 11 de maio de $19411^{88}$

- 25. o aniversário (bodas de prata): 19 de março a 2 de abril de 1944 (ver Fig. 6). ${ }^{89}$

\footnotetext{
80 "Notícias do Norte", 1 de junho de 1919.

81 "Notícias do Norte", 23 de novembro de 1919; "Diário do Minho", 16 e 22 de novembro de 1919.

82 "Diário do Minho", 30 de maio de 1920; "Os Sports", 6 de junho de 1920.

${ }^{83}$ Guimarães, J. A. e Guimarães, J. L. A. (s/d). A presidência de José Antunes Guimarães 1944/48: A história de um guerreiro, [edição do autor], Braga.

84 "Correio do Minho", 21 de fevereiro, 17 de março, 12, 24, 25, 28 e 29 de maio de 1934. Foi produzida uma revista relativa às celebrações deste aniversário: Sporting Clube de Braga (1934). Sporting Clube de Braga: 1919-1934. Revista comemorativa do 15. aniversário do clube.

85 "Correio do Minho", 19, 25, 28, 30 e 31 de maio e 1, 2 e 4 de junho de 1935. Foi produzida uma revista relativa às celebrações deste aniversário: Sporting Clube de Braga (1935). Semana desportiva do Sporting: 1919-1935. Revista comemorativa do 16. aniversário do clube..

86 "Correio do Minho", 4 a 16 de junho de 1936. Foi produzida uma revista relativa às celebrações deste aniversário: Sporting Clube de Braga (1936). Número comemorativo do XVII aniversário: 1919-1936. Revista comemorativa do 17. aniversário do clube.

87 "Correio do Minho", 13, 14, 15, 17 e 22 de maio de 1938.

88 "Correio do Minho", 15, 20 e 27 de abril, 3, 4, 6, 7, 8, 10, 11 e 13 de maio de 1941; Vieira, J. M. (1992). ABC 1933-1958: A doce idade. Académico Basket Club, Braga; Antunes Guimarães, M. P. "Braga: um clube centenário?”, in “O Jogo", 4 de agosto de 2019.

89 “Diário do Minho", 17, 18, 19, 21, 24, 25, 28, 31 de março, 2 e 4 de abril de 1944; Revista "Stadium”, 22 de março de 1944.
} 


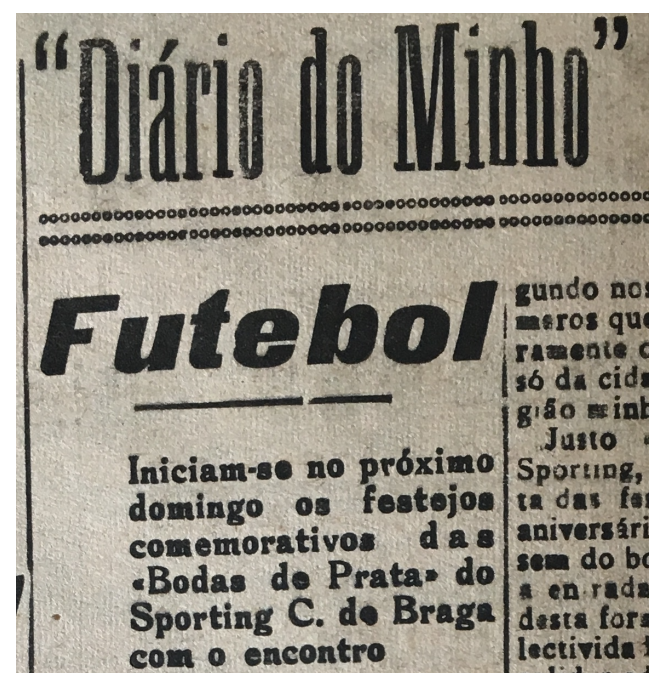

Figura 6 - Recorte do "Diário do Minho" (17 de março de 1944), relativo às comemorações dos 25 anos do SC Braga.

Em 1934, 1935 e 1936, foram editados números únicos que não deixam dúvidas algumas sobre o ano de fundação do clube (Fig. 7).
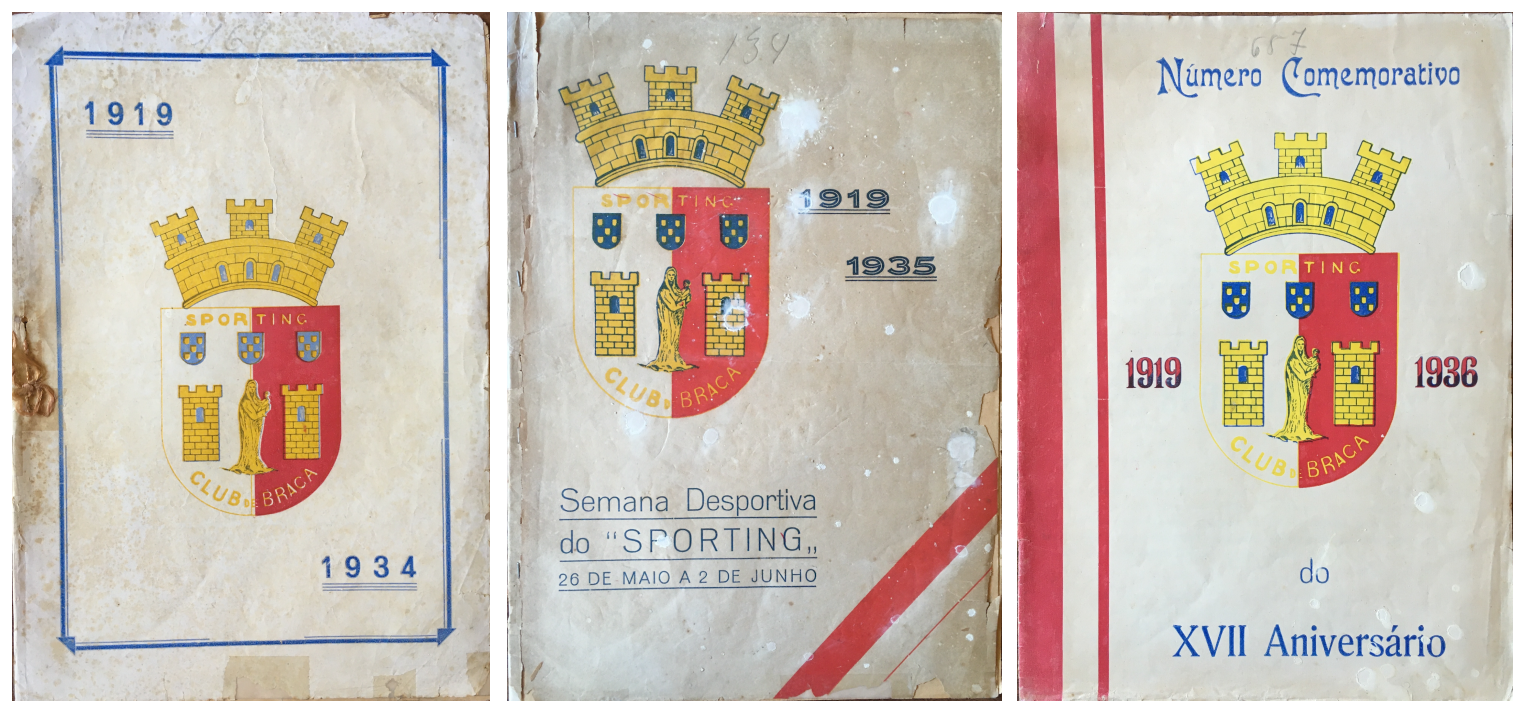

Figura 7 - Capas dos números únicos editados pelo clube para comemoração dos seus 15., 16. e 17.ำ aniversários, com indicação clara do ano fundacional de 1919.

Numa peça jornalística, publicada em março de 1938, com o título "Sejamos bairristas", é referido que o clube teria 18 anos, pelo que terá sido fundado entre março de 1919 e fevereiro de $1920 .^{90}$

Um outro artigo publicado na imprensa local refere que o "Sporting Club de Braga (...) na presente época completa o 20. o ano da sua existência" ${ }^{91}$ Se for interpretado que, à data do artigo, o SC Braga teria já completado 19 anos e portanto estava a cumprir o seu 20. ano de atividade, com estas duas informações pode balizar-se a fundação para o período entre março e setembro de 1919.

Joaquim de Oliveira e Costa, presidente do clube em 1922 e subscritor da documentação enviada ao COP, afirma que "a direção do S.C.B. vem trabalhando desde 1919 para aumentar a classe dos seus grupos de foot-ball". ${ }^{92}$

\footnotetext{
90 "Correio do Minho", 1 de março de 1938.

91 "Diário do Minho", 5 de outubro de 1938.

92 "Correio do Minho", 23 de abril de 1927.
} 
Mais tarde, volta a referir 1919 como o ano da fundação. ${ }^{93}$ Indica também que ele próprio foi jogador do clube entre 1919 e $1926 .{ }^{94}$ Afirma ainda no jornal do clube, ter colaborado com o SC Braga no período 1919-1928, após ter regressado da França do Corpo Expedicionário Português. ${ }^{95}$ Estas informações são coerentes com a notícia de novembro de 1919 que inclui Joaquim Costa no grupo de entusiastas que se dedicava à criação do SC Braga. ${ }^{96}$ Em 1970, parece ter surgido uma corrente que apontava o ano de 1920 como o da fundação do clube. Em outubro desse ano, a designada Comissão Executiva do Cinquentenário editou um jornal que resumia as atividades desenvolvidas para a comemoração dessa efeméride. A medalha comemorativa das bodas de ouro do clube também tem gravada as datas 1920-1970 (ver Fig. 8). 28 de fevereiro a 7 de março de $1970 .{ }^{97}$ De acordo com Barros Pereira, ${ }^{98}$ parece concluir-se que as efemérides relativas às bodas de ouro decorreram até fevereiro de 1970. Há contudo notícias que indicam que os atos comemorativos dos 50 anos se realizaram de 28 de fevereiro até 10 de junho de $1970 .{ }^{99}$ Poucos dias antes, Domingos Luz indicava que as bodas de ouro decorreriam de 28 de fevereiro de 1970 até 19 de janeiro de $1971,{ }^{100}$ ou seja, que decorreriam durante quase dez meses e que terminariam no exato dia em que se cumpriam os 50 anos de vida.
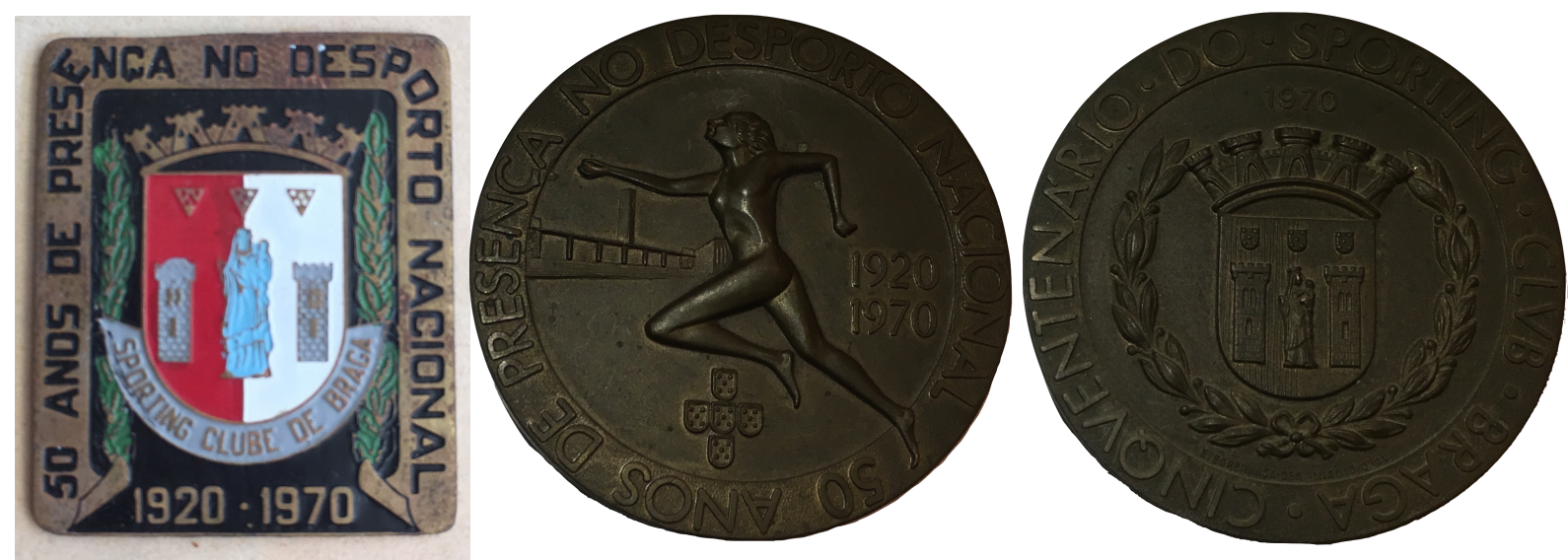

Figura 8 - Pin e medalha alusiva às bodas de ouro do clube que apontam para 1920 como ano fundacional.

Em junho de 1975, foi editado um livro de comemoração da última subida da equipa de futebol à I divisão, que indica que o SC Braga teria 55 anos. Contudo o autor refere que o clube foi fundado em 19 de janeiro de 1921, o que não deixa de ser curioso pela incoerência que significa. O livro da A.F. Braga também refere que o SC Braga terá sido fundado em fevereiro de $1920 .{ }^{101}$ Barros Pereira defende que o SC Braga deve ter sido pensado, fundado ou organizado algures entre finais de 1919 e princípios de $1920{ }^{102} \mathrm{Em}$ nenhum destes casos é referido o mês (e muito menos o dia) dessa fundação, nem é indicada qualquer base documental para suportar a proposta.

Mais específica é a notícia que refere um telegrama enviado por António Nogueira da Silva (sócio honorário n.o 1), a propósito das bodas de ouro do clube: ${ }^{103}$ "Ainda ontem [19 de janeiro], dia em que se efetuou, há 50 anos\} [1920], a reunião de que saiu a decisão de fundar o Clube (...)" Esta notícia aponta assim o dia 19 de janeiro de 1920 como aquele em que se decidiu a fundação do clube, reconhecendo explicitamente que a aprovação dos

\footnotetext{
93 “Correio do Minho", 2 de agosto de 1949.

94 "Correio do Minho", 28 de junho de 1949.

95 "Sporting Club de Braga", 17 de janeiro de 1960.

96 "Notícias do Norte", 23 de novembro de 1919.

97 "Diário do Minho", 20 de janeiro, 25 e 28 de fevereiro, 1, 7, 20 e 22 de março de 1970; reportagem da RTP em https://arquivos.rtp.pt/conteudos/50o-aniversario-do-sporting-clube-de-braga

${ }^{98}$ Barros Pereira, J. E. (1985). Sporting Clube de Braga 1921-1985. Correio do Minho, Braga, pp. 94-96; Barros Pereira, J. E. (2006). S. C. Braga: 85 anos de vida intensa (1921-2006). Sporting Clube de Braga, Braga, pp. 128-129.

99 "Correio do Minho", 6 de fevereiro de 1970.

100 "Correio do Minho", 29 de janeiro de 1970.

101 Delgado, F. N. e Guimarães, A. C. (1997). Associação de Futebol de Braga: subsídios para a história dos 75 anos. Braga, Associação de Futebol de Braga, Braga, p. 15.

102 Barros Pereira, J. E. (1985). Sporting Clube de Braga 1921-1985. Correio do Minho, Braga, p. 11.

103 "Diário do Minho", 20 de janeiro de 1970.
} 
estatutos só ocorreu em 1921, ou seja, que o clube já existia (eventualmente sem personalidade jurídica) antes desse ato formal. Esta data acaba por ser curiosa, pois é precisamente um ano antes da data que atualmente é a da fundação oficial. Estas informações que apontam para 1920 não têm suporte de base documental e podem ter surgido com o intuito de resolver o dilema 1919 vs. 1921. Contudo, reconhecem a existência do clube antes da legalização dos estatutos originais, realizada em 1921, e numa altura em que nos estatutos do clube já estava plasmada a data fundacional de 19 de janeiro de 1921.

Face a estas evidências todas, é inegável que em 1919 o SC Braga já existia como entidade coletiva, pelo que o dia 20 de março de 1919 pode ser adoptado sem grandes dúvidas como a data de fundação do SC Braga.

\section{Fundação em 1914}

Uma outra hipótese, que surgiu mais recentemente, aponta 1914 como ano de fundação do SC Braga. Uma peça do jornal "Echos do Minho", na edição de 16 de setembro de 1914, faz referência a um novo clube designado "Sporting Club de Braga" e lista os nomes dos diversos elementos dos seus corpos dirigentes. O "Jornal de Notícias" dá cobertura a este facto no mesmo dia. ${ }^{104}$ Uma segunda peça também publicada no "Echos do Minho", na edição de 8 de outubro de 1914, refere uma alteração na presidência do Conselho Fiscal. Estas duas verdadeiras descobertas, feitas por Evandro Lopes, abrem uma terceira via para a data de fundação do clube. ${ }^{105}$ Rui Ferreira, especialista em temas relacionados com a cidade de Braga, apresenta os dados biográficos dos membros fundadores do SC Braga de 1914 e mostra que muitos deles eram militares. ${ }^{106}$ Infelizmente, não há mais nenhuma informação sobre esse clube, nomeadamente a disputa de jogos, pelo que o mais provável é ter tido existência efémera, ou seja, ter-se extinto logo após a sua criação. Por exemplo, em maio de 1915, disputou-se um torneio de futebol em Braga, que serviu de inauguração ao campo das Goladas. Participaram o Football Club de Braga, o Sport Lisboa e Braga e o Minho Sport Club, ${ }^{107}$ pelo que a ausência desse SC Braga pode ser reveladora da sua extinção. É provável que não tenha sequer apresentado os seus estatutos ao Governo Civil, facto que terá permitido ao SC Braga fundado em 1919 legalizar-se, sem problemas com a sua designação.

$\mathrm{Na}$ eventualidade do SC Braga de 1914 ser o mesmo clube que retomaria a atividade mais tarde (1919-1921), o aparente hiato de 5 anos na sua atividade tem várias possíveis justificações. Desde logo, o facto de a I Grande Guerra Mundial se ter iniciado precisamente em 1914 é um primeiro e grande argumento. ${ }^{108}$ Em 1916, Portugal passa a participar de forma ativa nessa guerra, enviando tropas para França. Este facto obrigou muitos dos jovens que estavam ligados ao clube a interromper a sua prática desportiva em Braga para ir combater.

Também Miguel Sopas Bandeira afirma que faz sentido "admitir a anexação da fundação do SCB (...) ao ano de 1914". ${ }^{109}$ Para além da I Guerra Mundial, existem, segundo Bandeira, duas justificações principais para se ter verificado um forte abrandamento da atividade desportiva e social em Braga, no período 1914-1919.

Em primeiro lugar, a prática desportiva, nessa altura, era essencialmente informal, o que não exigia uma legalização do clube. Havia apenas jogos esporádicos (e raros) entre equipas. Não existia ainda um quadro competitivo perfeitamente organizado e formal. Por exemplo, o Campeonato de Portugal, a primeira prova oficial de carácter nacional, conheceu a sua primeira edição apenas em 1921/22. A União Portuguesa de Futebol, que viria a mudar mais tarde a sua designação para Federação Portuguesa de Futebol, foi fundada em 1914, pelas associações de Lisboa, Portalegre e Porto. ${ }^{110}$ A A.F. Braga foi apenas instituída a 27 de novembro de 1922 , sendo que o SC Braga, na pessoa de Celestino Lobo, foi um dos seus fundadores. ${ }^{111}$

Uma segunda grande causa desse recuo da atividade desportiva está relacionado com a grave pandemia de pneumónica (ou gripe espanhola) que fustigou Portugal. Essa pandemia chegou a Portugal em meados de 1918 e, em cerca de dois anos, dizimou dezenas de milhares de pessoas. Algumas zonas do país perderam cerca de $10 \%$

\footnotetext{
104 "Jornal de Notícias", 16 de setembro de 1914.

105 Lopes, E. e Dias, J. N. (2010). A história da "bola" em Braga: 1908-1947. Braga, pp. 100-101.

${ }^{106}$ Ferreira, R. (2019). Sporting Clube de Braga: Um clube centenário? Bracara Augusta, vol. LXVI, n. 124(127):425-450. Uma síntese do material deste artigo pode ser encontrada in "Diário do Minho", 5 de setembro de 2014.

107 "O Sport de Lisboa", 22 de maio de 1915.

108 Coelho, J. N. e Pinheiro, F. (2002). A paixão do povo: História do futebol em Portugal. Afrontamento, Porto, p. 347.

109 "Sporting Clube de Braga, 90 ou 97 anos de História?!", in "Diário do Minho", 21 de janeiro de 2011.

${ }^{110}$ Coelho, J. N. e Pinheiro, F. (2002). A paixão do povo: História do futebol em Portugal. Afrontamento, Porto, p. 155.

${ }^{111}$ Delgado, F. N. e Guimarães, A. C. (1997). Associação de Futebol de Braga: subsídios para a história dos 75 anos. Braga, Associação de Futebol de Braga, Braga, p. 16.
} 
da sua população, atingindo de forma mais grave e mortal a população mais jovem. Por exemplo, José Alvalade, fundador e ex-presidente do Sporting, morreu com apenas 33 anos, em outubro de 1918, vítima precisamente da pneumónica. Em termos de mortalidade, foi, para Álvaro Sequeira, a maior tragédia do séc. XX e provavelmente de toda a história de Portugal. ${ }^{112}$

Salvo melhor opinião e na linha do que já referiu Barreto Nunes ${ }^{113}$ e Miguel Pedro, ${ }^{114}$ com base na informação hoje disponível, não é possível estabelecer, com um grau elevado de confiança, a ligação entre os clubes de 1914 e de 1919-1921, apesar da coincidências de nomes. O nome "Sporting" era muito popular à época, tendo entre 1910 e 1925 sido fundados vários clubes em Portugal que têm esse termo na sua designação completa: SC Farense (1910), SC Olhanense (1912), Barcelos SC (1913), SC Espinho (1914), Portimonense SC (1914), SC Cruz (1919), SC Coimbrões (1920), Despertar SC de Beja (1920), SC Pombal (1922) e SC Covilhã (1923). Assim, é provável que, em dois momentos diferentes, dois grupos de pessoas tenham escolhido o mesmo nome. Não há documentos, notícias ou referências que indiquem que o SC Braga de 1919 é uma refundação ou continuidade do SC Braga de 1914. Contudo, a coincidência de nomes exige que seja uma hipótese a ter sempre em atenção e que necessita de ser mais bem explorada. O próprio Celestino Lobo refere o desaparecimento em Braga de todos os clubes no pós-guerra: "A Guerra de 1914 tinha terminado. (...) Os clubes há bem pouco formados tinham desaparecido". ${ }^{115}$ Parece razoável acreditar que algumas das pessoas que estiveram ligadas à criação do SC Braga de 1919-1921 teriam feito, em algum momento, a relação de continuidade com o clube de 1914, pois não se encontra nenhuma razão aparente para justificar a omissão desse facto se ele fosse verdadeiro. Aliás, se o clube tivesse sido refundado haveria todo o interesse (e até orgulho) em divulgar esse facto.

\section{Discussão}

Com base no que se apresentou nas três secções anteriores, discute-se aqui a data de fundação do SC Braga, considerando três alternativas:

- 19 de janeiro de 1921

- 20 de março de 1919

- 16 de setembro de 1914

Parte-se do princípio de que existe uma diferença conceptual entre fundação e constituição, traduzindo a primeira um facto determinante e de relevo, tido como o princípio da criação de um clube, e a segunda o ato formal e legal que traduz em registo legal a sua existência. Assim, fundação e constituição não são acontecimentos antagónicos, antes eventos de um mesmo processo evolutivo.

Procurou-se estabelecer pontes e relações entre eventos ocorridos naquele curto, mas exuberante, período de tempo, para encontrar afinidades entre os acontecimentos e as pessoas.

A data de 1914, trazida a público por Evandro Lopes e confirmada, pelos autores deste artigo, no Jornal de Notícias, ${ }^{116}$ é, sem dúvida, uma descoberta relevante que poderia acrescentar dúvidas quanto à data da fundação. O dia 16 de setembro de 1914 corresponde à data de notícias em dois jornais, que indicam a existência de um clube designado "Sporting Clube de Braga". No percurso de investigação, durante a qual todas as hipóteses forma mantidas em aberto, não foi possível estabelecer qualquer elo que pudesse indiciar, ainda que remotamente, uma ligação de 1914 ao SC Braga de 1919-1921. Nenhum dirigente daqueles que as notícias de 1914 trazem a público veio, por exemplo, a participar em qualquer processo, atividade ou iniciativa da fundação/constituição do SC Braga de 1919-1921, ou sequer em posteriores intervenções no âmbito do clube. Não seria essa situação, aliás, que retiraria validade às conclusões a que se chegou, mas não deixa de constituir um facto que contribui para fortalecer a tese que não há relação entre as notícias de 1914 e o SC Braga atual. É um facto que existiu um "SC Braga" em 1914, , que se terá extinguido pouco depois, num período de grande turbulência social. Sobram assim as alternativas de 1919 e 1921. A discussão entre 1919 e 1921 parece ter emergido em 1969, quando, Domingos Luz, na crónica semanal que publicava no Correio do Minho, escreveu que o SC Braga foi

\footnotetext{
${ }^{112}$ Sequeira, Á. (2001). A pneumónica. Medicina Interna, 8(1):49-55.

${ }^{113}$ Nunes, J. A. B. "Os primeiros jornais desportivos de Braga: Norte Desportivo de 1916 / Minho Desportivo de 1922", in "Diário do Minho", 17 de outubro de 2018.

${ }^{114}$ Antunes Guimarães, M. P. "É preciso definir, de uma vez por todas, a data de fundação", in "O Jogo".

115 "Sporting Club de Braga", 7 de novembro de 1959.

116 "Jornal de Notícias", 16 de setembro de 1914.
} 
fundado a 19 de janeiro de $1921 .{ }^{117}$ Na crónica da semana seguinte, ${ }^{118}$ anuncia que lhe chegaram informações que, na cidade de Braga, se contestava essa informação, pois o clube teria sido fundado em 1919. O assunto seria novamente abordado, ${ }^{119}$ agora com a referência que algumas pessoas afirmavam que o clube fora fundado em janeiro de 1919. Contudo, Domingos Luz contraria esta data, com base no art.o 1. dos estatutos do clube, que copia na sua crónica: "O SPORTING CLUB DE BRAGA, associação de utilidade pública nos termos da Lei n. 1.290, de 15 de Julho de 1922, fundado em 19 de Janeiro de $1921 . . .{ }^{120}$ Repare-se que Domingos Luz não está a referir-se aos estatutos originais (i.e., aqueles que foram remetidos ao Governo Civil em fevereiro de 1921), pois existe uma referência a uma lei posterior.

Durante as primeiras décadas da vida do SC Braga, a celebração da sua fundação, partilhada por todos aqueles que efetivamente estiveram nesse ato fundacional, foi sempre referida a 1919, não havendo ninguém que questionasse esse ano, embora a data precisa, dia e mês, não fosse uma preocupação. São inúmeros os artigos, revistas, declarações, referências, e, finalmente, documentos oficiais que, durante todos esses anos, apontam, com clareza singular, o ano de 1919. Há, inclusive notícias de 1919, pouco conhecidas até hoje, que expressam, claramente, que existiam movimentações para a formação de um clube na cidade de Braga que se iria chamar SC Braga. Mas, se havia muita informação veiculada por jornais e revistas que não deixavam qualquer dúvida quanto àquele ano, faltava algo que fosse um escrito legal, uma chancela de autenticidade, que dissipasse qualquer incerteza que pudesse existir. Quis a perseverança da investigação que fosse possível chegar a provas documentais oficiais que permitem considerar, de forma inequívoca, a data da fundação do clube. Trata-se de um documento oficial do SC Braga, datado de 1926, data muito próxima do período de 1919-1921, que refere não só o ano, mas também o dia e o mês da sua fundação: 20 março de 1919. Constitui uma espécie de "certidão de nascimento" vertida na documentação em que o SC Braga requer a sua constituição como entidade de utilidade pública e que consta do Arquivo do Comité Olímpico Português, juntamente com um "atestado" da Câmara Municipal de Braga onde esta reconhece "(...) que o Sporting Clube de Braga, sociedade desportiva organizada em 1919 (...)". Foi possível também descobrir aquele que terá sido o primeiro jogo publicitado num jornal, realizado em 24 de junho de 1920, dia de S. João e integrado nas suas festas (SC Braga 4-0 SC Caixeiros). Nele, alinharam vários jogadores que, mais tarde, viriam a ter uma ação relevante na primeira direção eleita, em 10 de fevereiro de 1921, responsável pelos estatutos desse ano, entregues no Governo Civil em 19 de fevereiro, assinados por vários desses atletas. Esta ligação pessoal, de um facto muito relevante ocorrido em 1920, faz a ponte que completa a ligação entre os acontecimentos noticiados em 1919 e os de 1921.

\section{Conclusão}

Este artigo aborda a questão da fundação do SC Braga. Foram investigadas centenas de páginas de documentos jornalísticos e oficiais, opiniões expressas em estudos elaborados por investigadores do assunto, auscultadas as opiniões de defensores das diferentes datas tidas como alternativas, ouvidos testemunhos orais de pessoas que privaram de uma forma muito próxima com os "fundadores" do clube, num levantamento exaustivo e criterioso. Como se referiu no início deste artigo, a escolha da data fundacional depende em grande medida do facto que for usado para a estabelecer. A existência de um documento oficial do clube (de 1926), assinado por um dirigente do clube e incluído num processo formal, que indica claramente a data de fundação como sendo o dia 20 de março de 1919 é suficientemente forte, para ser aceite sem grande dúvidas. Se forem tomadas em atenção todas as inúmeras evidências para a existência do clube em 1919 e 1920, rapidamente se percebe que é uma informação altamente credível, já que não é uma data que surge fora de contexto. A data que é usada atualmente como da fundação do clube (19 de janeiro de 1921) é a que resulta do documento mais antigo que era conhecido (embora com o erro crasso de um mês), mas é claramente posterior a muitas das iniciativas que permitiram que o SC Braga fosse criado. Além disso, trata-se da data de constituição do clube e não da sua fundação.

A discussão feita na secção anterior leva-nos a considerar que o Sporting Clube de Braga foi fundado no dia 20 de março de 1919 e constituído no dia 19 de fevereiro de 1921.

Os argumentos fundamentais que sustentam esta afirmação são os seguintes:

1. Fundação e constituição são conceitos distintos e não antagónicos, antes complementares;

\footnotetext{
${ }^{117}$ Na realidade, afirma que o clube faria 48 anos no dia 19 de janeiro de 1969; "Correio do Minho", 3 de janeiro de 1969.

118 "Correio do Minho", 9 de janeiro de 1969.

119 "Correio do Minho", 20 de janeiro de 1969.

120 "Correio do Minho", 20 de março de 1969.
} 
2. Há evidências documentais profusas e coerentes, durante as primeiras quatro décadas da existência do clube, veiculadas, entre outros, por dirigentes que estiveram na fundação do SC Braga que apontam sempre 1919 como o ano da sua fundação;

3. A descoberta no Arquivo do Comité Olímpico Português de dois documentos oficiais, um do clube e outro da Câmara Municipal de Braga, que referem, clara e expressamente, que a data da fundação ocorreu em 20 de março de 1919, reforçam e dão caráter institucional a 1919 como ano fundacional;

4. Está comprovada a existência de atividade desportiva do SC Braga antes de 1921, nomeadamente o jogo de 24 de junho de 1920, bem como notícias da imprensa em 1919 e 1920 referindo a existência de diligências para a organização de um clube que teria a designação de SC Braga;

5. Não foram encontradas quaisquer provas que evidenciem a ligação do "SC Braga" de 1914 ao SC Braga atual;

6. A data de 19 de janeiro de 1921 constitui um erro grosseiro, sem qualquer suporte documental, ao contrário de 19 de fevereiro de 1921, esta sim, a data em que os estatutos do clube foram apresentados no Governo Civil;

\section{Agradecimentos}

Os autores agradecem a X, Y, Z, por terem lido, revisto e comentado uma versão preliminar deste artigo.

\section{Referências bibliográficas}

Delgado, F. N. e Guimarães, A. C. (1997). Associação de Futebol de Braga: subsídios para a história dos 75 anos. Braga, Associação de Futebol de Braga, Braga.

Alves, A. (1993). Silves Futebol Clube: 74 anos de história. AA Publicações / Silves Futebol Clube, Loulé.

Alves, A. (2003). Portimonense Sporting Clube: 89 anos de história, 1914-2003. Portimonense Sporting Clube, Portimão.

Alves, A. (2012). Sporting Clube Olhanense: Honra e glória. Sporting Clube Olhanense, Olhão.

Barreto, A. e Mónica, M. F. (1999). Dicionário de história de Portugal. Livraria Figueirinhas, Lisboa.

Barros Pereira, J. E. (1985). Sporting Clube de Braga 1921-1985. Correio do Minho, Braga.

Barros Pereira, J. E. (2006). S. C. Braga: 85 anos de vida intensa (1921-2006). Sporting Clube de Braga, Braga.

Bernardino, A. e Machado, P. (2013). Moreirense FC - 1938/2013: Trabalho, dedicação, história. Moreirense Futebol Clube, Moreira de Cónegos.

Bragaglia, P. (1996). Club Sport Marítimo: 85 anos de história. Club Sport Marítimo, Ponta Delgada.

Cavaco, H. (1991). Luzitano Foot-ball Club (1916/1991): “Origens - Percurso - Actualidade”. Câmara Municipal de Vila Real de Santo António, Vila Real de Santo António.

Cavaco, H. (2002). Lusitano Futebol Clube: Arca de memórias. Câmara Municipal de Vila Real de Santo António, Vila Real de Santo António.

Ceitil, J. (2009). Clube de Futebol Os Belenenses: 90 anos de história. Âncora Editora, Lisboa.

Ferreira J. F. C. (1996). História do Futebol Clube de Penafiel fundado em 8-2-1951 e antigos clubes penafidelenses. Futebol Clube de Penafiel, Penafiel.

Coelho, J. N. e Pinheiro, F. (2002). A paixão do povo: História do futebol em Portugal. Afrontamento, Porto.

Dias, M. T. (2005). Sporting Clube de Portugal: Uma história diferente. Fubu Editores, Porto.

Estanislau, D. (1993). História do Clube Futebol Benfica. Clube Futebol Benfica, Lisboa.

Ferreira, R. (2019). Sporting Clube de Braga\}: Um clube centenário? Bracara Augusta, vol. LXVI, n. 124(127):425450. Uma síntese do material deste artigo pode ser encontrada in “Diário do Minho", 5 de setembro de 2014.

Figueiredo, J. R. (1986). 70 anos de vida do Futebol Clube Barreirense.

Figueiredo, V. (2013). Clube Oriental de Lisboa: Histórias do nosso clube. Clube Oriental de Lisboa, Lisboa.

Galego, B. E. (2001). Leixões Sport Club: Marcos importantes da sua história (1907/2000). Editorial Maresia.

Gonçalves, J. C. (2013). “Os Limianos” e a história do futebol em Ponte de Lima. Câmara Municipal de Ponte de 
Lima, Ponte Lima.

Guimarães, J. A. e Guimarães, J. L. A. (s/d). A presidência de José Antunes Guimarães 1944/48: A história de um guerreiro.

Higino, L. F. (2003). Clube Desportivo Feirense: Breve história cronológica (85 anos, 1918-2003). Clube Desportivo Feirense, Santa Maria da Feira.

Lopes, E. e Dias, J. N. (2010). A história da “bola” em Braga: 1908-1947. Braga.

Lopes, R. P. (2009). Sertanense: 75 anos de história (1934-2009). Câmara Municipal da Sertã, Sertã.

Machado, M. e Lobo, A. (1997). Vitória Sport Clube: 75. aniversário. Vitória Sport Clube, Guimarães.

Maia, R., Higino, L. F., Brandão, A., e Santos, G. (2010). Memórias avulsas de Rui Maia: 50.o aniversário da geração de ouro de 1960 do Clube Desportivo Feirense. Clube Desportivo Feirense, Santa Maria da Feira.

Moreira, G. (1980). A história do ciclismo português. [edição do autor], Alcobaça.

Neto, D. e Silva, P. (1999). Associação Desportiva Sanjoanense: 75 anos de história (1924-1999). Laborpress, São João da Madeira.

Nunes, J. J. (1993). Figuras e factos do Sporting Clube da Covilhã. Sporting Clube da Covilhã, Covilhã.

Nóbrega, T. (2010). Nacional 1910-2010: Álbum do centenário. Clube Desportivo Nacional, Funchal.

Pacheco, H. (2011). Académico Futebol Clube: Um século na vida portuense, ao serviço do desporto.

Afrontamento, Porto.

Pinto, A. (2007). Futebol de Felgueiras - nas fintas do tempo: 1932/2007. [edição do autor], Felgueiras.

Pinto, J. S. e Tavares, H. (1990). Casa Pia Atlético Clube (Ateneu Casapiano). Biblioteca-Museu Luz Soriano, Lisboa. Sporting Clube de Braga (1934). Sporting Clube de Braga: 1919-1934. Revista comemorativa do 15. aniversário do clube.

Sporting Clube de Braga (1935). Semana desportiva do Sporting: 1919-1935. Revista comemorativa do 16. aniversário do clube.

Sporting Clube de Braga (1936). Número comemorativo do XVII aniversário: 1919-1936. Revista comemorativa do 17. aniversário do clube.

Sporting Clube de Braga (1996). 75 anos de alma e coração: 1921-1996. Revista comemorativa dos 75 anos do clube.

Sequeira, Á. (2001). A pneumónica. Medicina Interna, 8(1):49-55.

Serrado, R. (2010). Cosme Damião: O homem que sonhou o Benfica. Zebra Publicações, Lisboa.

Serrado, R. e Serra, P. (2014). História do futebol português: Uma análise social e cultural. 2 volumes, Prime Books, Lisboa.

Silva, J. B. P. (2000). Aliados Futebol Clube de Lordelo. Anégia Editores, Lordelo.

Viana, R. A. F., Peixoto, A. M., e Silva, P. P. (1998). S. C. Vianense: 100 anos de história em datas (1898-1998).

Sport Clube Vianense, Viana do Castelo.

Vicente, L. (2014). União de Tomar: 100 anos de história [1914-2014]. Tomar.

Vieira, J. M. (1992). ABC 1933-1958: A doce idade. Académico Basket Club, Braga.

Vila Cova, A. (2010). Varzim S.C.: Orgulho de um povo. Póvoa de Varzim. 